\title{
Plant Phenolics and Phenolic-Enriched Extracts as Antimicrobial Agents against Food-Contaminating Microorganisms
}

\author{
Miklós Takó ${ }^{1, * \mathbb{C}}$, Erika Beáta Kerekes ${ }^{1}$, Carolina Zambrano ${ }^{1}$, Alexandra Kotogán ${ }^{1}$, \\ Tamás Papp ${ }^{1,2}\left(\mathbb{D}\right.$, Judit Krisch ${ }^{3}(1)$ and Csaba Vágvölgyi ${ }^{1}(\mathbb{C}$ \\ 1 Department of Microbiology, Faculty of Science and Informatics, University of Szeged, Közép fasor 52, \\ H-6726 Szeged, Hungary; kerekeserika88@gmail.com (E.B.K.); czambranocarrillo@gmail.com (C.Z.); \\ primula15@gmail.com (A.K.); pappt@bio.u-szeged.hu (T.P.); csaba@bio.u-szeged.hu (C.V.) \\ 2 MTA-SZTE “Lendület" Fungal Pathogenicity Mechanisms Research Group, University of Szeged, \\ Közép fasor 52, H-6726 Szeged, Hungary \\ 3 Institute of Food Engineering, Faculty of Engineering, University of Szeged, Mars tér 7, \\ H-6724 Szeged, Hungary; krisch@mk.u-szeged.hu \\ * Correspondence: tako78@bio.u-szeged.hu; Tel.: +36-62-544-516
}

Received: 28 January 2020; Accepted: 16 February 2020; Published: 18 February 2020

\begin{abstract}
Phenolic compounds and extracts with bioactive properties can be obtained from many kinds of plant materials. These natural substances have gained attention in the food research as possible growth inhibitors of foodborne pathogenic and spoilage bacteria. Many phenolic-enriched plant extracts and individual phenolics have promising anti-quorum sensing potential as well and can suppress the biofilm formation and toxin production of food-related pathogens. Various studies have shown that plant phenolics can substitute or support the activity of synthetic food preservatives and disinfectants, which, by the way, can provoke serious concerns in consumers. In this review, we will provide a brief insight into the bioactive properties, i.e., the antimicrobial, anti-quorum sensing, anti-biofilm and anti-enterotoxin activities, of plant phenolic extracts and compounds, with special attention to pathogen microorganisms that have food relation. Carbohydrase aided applications to improve the antimicrobial properties of phenolic extracts are also discussed.
\end{abstract}

Keywords: phenolic antioxidants; antimicrobials; quorum sensing; biofilm; enterotoxin; foodborne pathogens; spoilage bacteria; carbohydrase aided extraction

\section{Introduction}

Phenolic compounds are secondary metabolites in plants and are considered as important natural molecules due to their bioactive properties. Phenolics are eliminators of free radicals and metal chelators. They can inhibit the lipid peroxidation and exhibit various physiological activities as antioxidants. In plants, these substances contribute to the defense mechanisms, and adaptation and pigmentation processes. Concerning human health, they have potential in the prevention and treatment of certain chronic diseases such as cardiovascular disease, diabetes and cancer [1]. In addition, plant phenolics and extracts rich in such substances can be excellent inhibitors of many foodborne pathogenic and spoilage bacteria [2,3]. Various food-related bacteria have biofilm-forming ability and can cause serious contaminations in the food industry. Quorum sensing, as a mechanism of bacterial cell-to-cell chemical communication, plays an important role in biofilm formation, antibiotic resistance, survival, proliferation and toxin production of the pathogens. Inhibition of this signaling process can contribute to the biological control of pathogenic organisms and bacterial toxins causing food deterioration and/or poisoning [4]. 
Byproducts of antioxidative plants generated through agro- and food industrial processes are excellent sources of bioactive phenolic materials with antimicrobial effects [5]. Physical and chemical extractions are common methods to obtain these active compounds from plants, but solid-state fermentation and enzyme assisted extraction procedures using carbohydrase active microorganisms or enzymes, can also be useful approaches [6-8].

Due to the growing knowledge on their bioactive values, use of plant phenolics as natural additives has recently gained interest in the food industry. Several studies demonstrated the potential of these antioxidant and antimicrobial compounds as food preservatives as well as functional food ingredients [9-11]. In this respect, phenolic acids, flavonoids and tannins have gained special attention over the last decades [2,12].

This review emphasizes the importance of using plant phenolics as natural alternatives of synthetic compounds to eliminate pathogens and spoilage bacteria from food environments. Also, this review deals on the inhibitory potential of phenolic antioxidants against the quorum sensing system, biofilm formation and enterotoxin production of food-related microorganisms. Some studies to improve the phenolic-related antimicrobial activity of plant extracts by using carbohydrases are also highlighted.

\section{Foodborne Pathogens and Food Spoilage Organisms}

Foodborne diseases constitute a global health problem. During the infection, pathogenic bacteria and/or microbial toxins produced enter to the human body through the contaminated food or water. Pathogenesis varies according to the host's health conditions, the type of microorganisms and the amount of the agent to which the host is initially exposed. Common examples of food and waterborne outbreaks are the Staphylococcus aureus food poisoning and the Salmonella Typhimurium infection, which cause toxic symptoms and gastrointestinal infection. Table 1 presents some common foodborne pathogenic bacteria, their sources and produced toxins as well as the diseases caused.

Table 1. Most common foodborne pathogenic bacteria, their produced toxins and diseases caused.

\begin{tabular}{|c|c|c|c|c|}
\hline $\begin{array}{c}\text { Foodborne Pathogen } \\
\text { Bacteria }\end{array}$ & Toxin Production & Type of Disease & $\begin{array}{l}\text { Main Food Sources of } \\
\text { Infection }\end{array}$ & Reference \\
\hline Bacillus cereus & $\begin{array}{l}\text { Emetic toxin, } \\
\text { diarrheal toxin }\end{array}$ & $\begin{array}{c}\text { Emetic syndrome, } \\
\text { diarrhea }\end{array}$ & Rice, pasta, noodles, pastry & {$[13]$} \\
\hline $\begin{array}{l}\text { Campylobacter coli, } \\
\text { Campylobacter jejuni }\end{array}$ & $\begin{array}{c}\text { Cytolethal } \\
\text { distending toxin }\end{array}$ & Campylobacteriosis & $\begin{array}{l}\text { Poultry products, } \\
\text { unpasteurized milk }\end{array}$ & {$[14,15]$} \\
\hline Clostridium botulinum & Botulinum toxin & Botulism & $\begin{array}{l}\text { Improperly processed } \\
\text { canned foods }\end{array}$ & {$[13]$} \\
\hline Escherichia coli O157:H7 & Shiga-toxin & $\begin{array}{l}\text { Hemorrhagic } \\
\text { colitis }\end{array}$ & $\begin{array}{l}\text { Ground meats, raw or } \\
\text { under-pasteurized milk, } \\
\text { sprouts }\end{array}$ & {$[13,15]$} \\
\hline Listeria monocytogenes & Listeriolysin $\mathrm{O}$ & Listeriosis & $\begin{array}{l}\text { Soft cheeses from } \\
\text { unpasteurized milk, } \\
\text { ready-to-eat products }\end{array}$ & {$[15,16]$} \\
\hline $\begin{array}{c}\text { Salmonella Typhi, } \\
\text { Salmonella } \\
\text { Typhimurium, } \\
\text { Salmonella Enteritidis }\end{array}$ & Enterotoxin & $\begin{array}{l}\text { Typhoid fever, } \\
\text { salmonellosis } \\
\text { (gastroenteritis) }\end{array}$ & $\begin{array}{l}\text { Any type of food: meat, } \\
\text { poultry, fish, milk, eggs, } \\
\text { vegetables, water }\end{array}$ & {$[13,15]$} \\
\hline Staphylococcus aureus & $\begin{array}{l}\text { Heat stable } \\
\text { enterotoxins }\end{array}$ & $\begin{array}{l}\text { Gastrointestinal } \\
\text { symptoms }\end{array}$ & $\begin{array}{c}\text { Meat, dairy products, } \\
\text { salads }\end{array}$ & {$[13]$} \\
\hline $\begin{array}{c}\text { Vibrio cholerae, Vibrio } \\
\text { parahaemolyticus, Vibrio } \\
\text { vulnificus }\end{array}$ & Cholera toxin & $\begin{array}{l}\text { Cholera, } \\
\text { gastroenteritis }\end{array}$ & $\begin{array}{l}\text { Raw/undercooked } \\
\text { shellfish, meat, } \\
\text { contaminated water }\end{array}$ & {$[13]$} \\
\hline
\end{tabular}

Certain food pathogens can survive under adverse environmental factors such as cold, heat, acidic and high salt conditions and have the capacity to form biofilms on biotic or abiotic surfaces. These properties can facilitate their growth and spread on food contact surfaces as well. 
On the other hand, the consumption of raw products, such as fruits and vegetables, packaged salads and ready-to-eat products has increased. This can cause diseases by exposing consumers to a greater variety of products potentially contaminated with food pathogens [17]. Moreover, the misuse and overuse of anti-infective drugs against pathogenic microorganisms has generated greater resistance to clinical antibiotic therapy, acquiring the ability to survive at high drug concentration that cause serious diseases and/or chronic infections [18,19].

Microbiological deterioration of foods adversely affects their physico-chemical properties and thereby the sensory characteristics. Texture softening, slime production, off-odors, off-flavors and colorization are the main signs of food spoilage. The main spoiling microbes in animal-derived products (e.g., milk, dairy, meat and poultry) are Enterobacteriaceae, lactobacilli, Pseudomonas, Proteus and Brochotrix species [20]. Yeasts and molds, i.e., Saccharomyces, Candida, Pichia, Aspergillus, Penicillium, Botrytis and Fusarium species, and bacteria such as pseudomonads, clostridia, bacilli and Erwinia are common spoilers in plant-derived products [20-22].

Prevention and control of foodborne pathogens and spoilers require their detection in the food. Conventional methods rely on culturing of microorganisms on special media allowing their identification and enumeration. These methods are precise but time- and labor-consuming. Some rapid detection method based on nucleic acids sequencing, metabolomics and proteomics have been developed in the recent decades $[23,24]$. Matrix-assisted laser desorption/ionization time-of-flight mass spectrometry (MALDI-TOF MS) can be used for the identification of pathogens through analysis of the whole cell proteome. Metabolites produced by pathogens or spoilers are detected by means of gas chromatography-mass spectrometry (GC-MS) or electronic nose [25]. Immunological methods, such as the enzyme-linked immunosorbent assay (ELISA), are also used for rapid detection of certain pathogens (e.g., Salmonella) [23]. For prevention and control of foodborne microorganisms, physical and chemical methods, like sterilization, pasteurization, irradiation, high hydrostatic pressure or preservatives can be used.

Some of these foodborne pathogenic and spoilage microorganisms became tolerant against the conventional food preservation and conservation methods [2]. There is a significant industrial demand for novel preservation techniques because of the common food losses due to microbial deterioration. Moreover, the consumers' concern against the chemical preservatives in foods is growing, which also encourages the researchers to find natural alternatives with high antimicrobial potential. These substances then can be used as preservative agents to improve the shelf life of food products. Plant phenolic substances can be promising candidates for these studies.

\section{Antimicrobial Activity of Plant Phenolics}

Plant-derived phenolics, such as phenolic acids, flavonoids, stilbenes and tannins, can inhibit the growth and activity of many microorganisms, including food-related pathogens as well as clinically important bacteria, fungi and protozoa [26-28]. Since the different molecules vary in their structure and chemical composition (Figure 1), they can display various antimicrobial effects, such as permeabilization and destabilization of the plasma membrane or inhibition of extracellular enzymes [29]. Moreover, these mechanisms of action differ from those of the traditional antibiotics, which could make plant phenolics effective against drug-resistant pathogens [29]. 


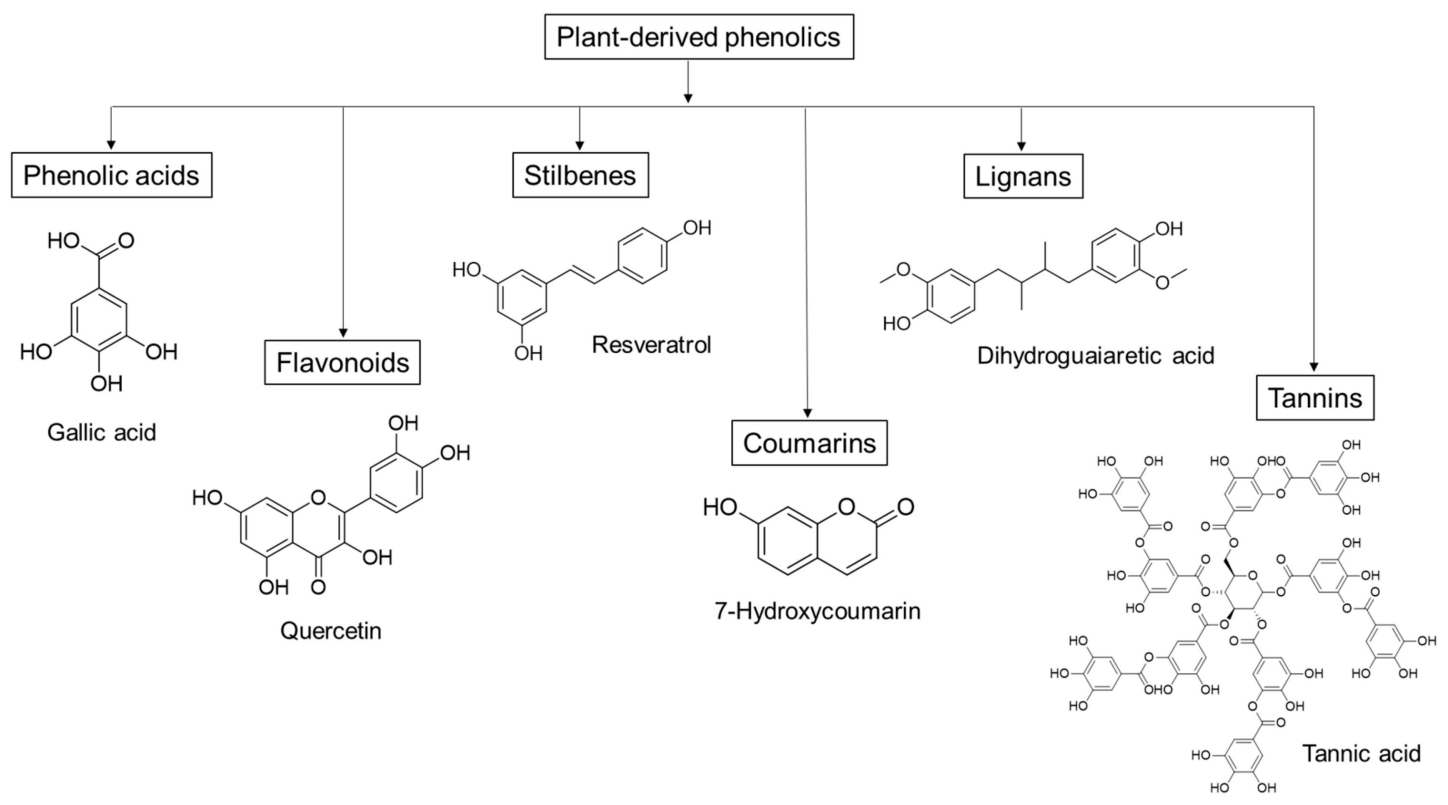

Figure 1. Groups of plant-derived phenolics, and some representative antimicrobial compounds with their chemical structure.

Extracts of grape pomace, grape seed, apple, and various exotic fruit and medicinal plant samples are frequently examined for their potential antimicrobial activity. In a pilot research, for instance, the influence of grape pomace extract on the growth of 14 pathogenic and spoilage bacteria was investigated [30]. In agar well diffusion tests, the order of the effective extract concentrations were found to be $20>10>5>2.5>1 \%(w / v)$, while in serial dilution assays, the sample at $0.5 \%(w / v)$ concentration had a bacteriostatic activity against Escherichia coli O157:H7 and S. aureus. In another study, red grape pomace possessed a strong bactericidal effect against E. coli and S. aureus at $12 \mathrm{mg} / \mathrm{mL}$ concentration [31]. The growth inhibitory effect, tested at concentrations from 0.5 to $2 \mathrm{mg} / \mathrm{mL}$, varied in a dose dependent manner, and the $S$. aureus was more susceptible to the grape pomace extract than the E. coli strain tested. Grape seed extracts were also proved to be effective growth suppressors of other food-related bacteria such as $S$. Typhimurium, Listeria monocytogenes, Bacillus spp., Pseudomonas aeruginosa and Campylobacter spp. [32-34]. Among exotic fruits, extracts and betacyanin fractions of red pitahaya exhibited a good antimicrobial spectrum against Gram-positive and Gram-negative bacteria, yeasts and molds at concentrations from $7.8 \mu \mathrm{g} / \mathrm{mL}$ to $50 \mathrm{mg} / \mathrm{mL}[35,36]$. Table 2 summarizes some additional examples about the antimicrobial activity of plant phenolic extracts, indicating the type of extraction and major antimicrobial activity indices. 
Table 2. Antimicrobial activity of plant phenolic extracts, some examples.

\begin{tabular}{|c|c|c|c|c|}
\hline Plant Materials & Type of Extraction & Target Organism & Antimicrobial Activity & Reference \\
\hline \multicolumn{5}{|c|}{ Fruit samples } \\
\hline Red wine grape pomace & $\begin{array}{c}70 \% \text { acetone } / 0.1 \% \mathrm{HCl} / 29.9 \% \\
\text { water }(v / v / v)\end{array}$ & Escherichia coli, Listeria innocua & $\begin{array}{c}\text { Pinot Noir-pomace and skin MIC }{ }^{1} \text { : E. coli, } 3 \% \text { and } 6 \% ; \text { L. innocua, } \\
2 \% \text { and } 7 \% \\
\text { Merlot-pomace and skin MIC: E. coli, } 9 \% ; \text { L. innocua, } 8 \%\end{array}$ & [37] \\
\hline Apple peel & Ethanol & $\begin{array}{l}\text { Lactobacillus acidophilus, Lactobacillus bulgaricus, } \\
\text { Lactobacillus plantarum, Lactobacillus rhamnosus, } \\
\text { E. coli, Bacillus cereus, Staphylococcus aureus }\end{array}$ & $\begin{array}{l}\text { Extract concentration: } 2-20 \mu \mathrm{g} / \text { disk } \\
\text { B. cereus and E. coli: inhibition haloes of } 6 \text { to } 14 \mathrm{~mm} \\
\text { Probiotic lactobacilli: no inhibition } \\
\text { S. aureus: no inhibition }\end{array}$ & [38] \\
\hline $\begin{array}{l}\text { Red and white grape } \\
\text { pomaces }\end{array}$ & Acetone & $\begin{array}{c}\text { Listeria monocytogenes, S. aureus, E. coli O157:H7, } \\
\text { Salmonella Typhimurium }\end{array}$ & $\begin{array}{c}\text { MIC (mg/mL): L. monocytogenes, } 4.69-18.8 ; \text { S. aureus, } 40.6-250 \\
\operatorname{MBC}^{2}(\mathrm{mg} / \mathrm{mL}): \text { L. monocytogenes, } 9.38-37.5 ; \text { S. aureus, }>250 \\
\text { E. coli: no inhibition } \\
\text { S. Typhimurium: no inhibition }\end{array}$ & [39] \\
\hline $\begin{array}{l}\text { Cinnamon bark and Ajowan } \\
\text { fruit }\end{array}$ & Acetone, ethanol & $\begin{array}{c}\text { Pseudomonas sp., Bacillus subtilis, E. coli, S. } \\
\text { aureus }\end{array}$ & $\begin{array}{l}\text { MIC values }(\mu \mathrm{g} / \mathrm{mL}) \text { : } \\
\text { ethanol extract of cinnamon, 32-64; ethanol extract of Ajowan, } \\
\text { 32-64; acetone extracts of cinnamon, 16-64; Acetone extract of } \\
\text { Ajowan, 64-128 }\end{array}$ & [40] \\
\hline $\begin{array}{l}\text { Blackberry and blueberry } \\
\text { pomaces }\end{array}$ & $10 \%$ methanol, $10 \%$ ethanol & Campylobacter jejuni & $\begin{array}{l}\text { MIC (mg/mL GAE): blackberry, 0.6; blueberry, } 0.4 \\
\text { MBC (mg/mL GAE): blackberry, 0.8; blueberry, } 0.5\end{array}$ & [41] \\
\hline Blueberry puree & $75 \%$ ethanol & L. monocytogenes, Salmonella Enteritidis & MIC (mg/mL): L. monocytogenes, 300-750; S. Enteritidis, 400-1200 & [42] \\
\hline Apple pomace & Ethyl acetate & S. aureus, E. coli & MIC (mg/mL): S. aureus, $1.25 ;$ E. coli, 2.50 & [43] \\
\hline $\begin{array}{l}\text { Black grape pomace, apple } \\
\text { and pitahaya residues }\end{array}$ & $\begin{array}{l}10 \% \text { ethanol after enzyme-aided } \\
\text { extraction }\end{array}$ & $\begin{array}{l}\text { B. subtilis, B. cereus, L. monocytogenes, S. aureus, } \\
\text { methicillin-resistant S. aureus, E. coli, S. } \\
\text { Typhimurium, Pseudomonas putida, P. aeruginosa }\end{array}$ & MICs: from 12.5 to $\geq 100 \mathrm{mg} / \mathrm{mL}$ & [3] \\
\hline Bayberry & Ethanol & $\begin{array}{c}\text { S. aureus, L. innocua, } \beta \text {-hemolytic Streptococcus, } \\
\text { S. Enteritidis, Salmonella typhi, Shigella } \\
\text { dysenteriae }\end{array}$ & $\begin{array}{c}\text { Diameter of inhibition (mm): } \\
\text { S. aureus, 22.9; L. innocua, 21.5; } \beta \text {-hemolytic Streptococcus, 22.7; S. } \\
\text { Enteritidis, 20.1; S. typhi, 13.3; S. dysenteriae, } 19.3\end{array}$ & [44] \\
\hline Grape pomace & $50 \%$ methanol, $50 \%$ ethanol & S. aureus, E. coli, P. aeruginosa, Candida albicans & $\begin{array}{c}\text { Extract concentration: } 1 \mathrm{mg} / \text { disk } \\
\text { Diameter of inhibition }(\mathrm{mm}): \\
\text { C. albicans, } 12-13 \\
\text { S. aureus, E. coli, P. aeruginosa: no inhibition }\end{array}$ & [45] \\
\hline Grape residues & $\begin{array}{l}\text { Ultrasound-assisted extraction, } \\
\text { methanol:acetone: water:acetic } \\
\text { acid (30:42:27.5:0.5) }\end{array}$ & $\begin{array}{c}\text { Clostridium perfringens, B. cereus, } L . \\
\text { monocytogenes, S. aureus, Sarcina lutea, } \\
\text { Micrococcus flavus, E. coli, P. aeruginosa, } S . \\
\text { Enteritidis, Shigella sonnei, Klebsiella pneumoniae, } \\
\text { C. albicans }\end{array}$ & $\begin{array}{c}\text { Extract concentration: } 30 \mu \mathrm{g} / \text { disk } \\
\text { Diameter of inhibition }(\mathrm{mm}) \text { : } \\
\text { C. perfringens, 15.9-17.7; B. cereus, 15.2-17.1; L. monocytogenes, } \\
\text { 16.4-18.5; S. aureus,16.5-18.5; S. lutea, 17.3-19.7; M. flavus, 14.8-16.9; } \\
\text { E. coli, 12.1-15.7; P. aeruginosa, 13.5-15.9; S. Enteritidis, 13-15.4; S. } \\
\text { sonnei, 15.6-17.7; K. pneumoniae, 15-16.6; C. albicans, 13.1-15.5 }\end{array}$ & [46] \\
\hline
\end{tabular}


Table 2. Cont

\begin{tabular}{|c|c|c|c|c|}
\hline Plant Materials & Type of Extraction & Target Organism & Antimicrobial Activity & Reference \\
\hline Grape marc waste & $\begin{array}{l}\text { Aqueous extraction and } \\
\text { Amberlite FPX-66 purification }\end{array}$ & E. coli, S. aureus, C. albicans & MBC $(\%, w / v):$ E. coli, $2 ;$ S. aureus, $0.125 ;$ C. albicans, no effect & [47] \\
\hline Apple phenolic fractions & $\begin{array}{l}\text { Acetone:ethanol (1:3), solid } \\
\text { phase extraction }\end{array}$ & $\begin{array}{l}\text { L. monocytogenes, S. aureus, E. coli, S. } \\
\text { Typhimurium }\end{array}$ & $\begin{array}{c}\text { Extract concentration: } 10-5000 \mu \mathrm{g} / \text { disk } \\
\text { Diameter of inhibition }(\mathrm{mm}) \text { : } \\
\text { L. monocytogenes, 3.7-14.6; S. aureus, 10.9-17.6; E. coli, 7.5; S. } \\
\text { Typhimurium, 4.5-7 }\end{array}$ & [48] \\
\hline \multicolumn{5}{|c|}{ Medicinal plants and herbs } \\
\hline $\begin{array}{l}\text { Punica granatum L. var. } \\
\text { pleniflora flowers }\end{array}$ & Ethanol & $\begin{array}{l}\text { S. aureus, B. cereus, L. monocytogenes, E. coli, S. } \\
\text { dysenteriae, S. typhi }\end{array}$ & $\begin{array}{c}\text { Extract concentration: } 50 \mathrm{mg} / \mathrm{well} \\
\text { Diameter of inhibition }(\mathrm{mm}): \\
\text { S. aureus, 32; B. cereus, 28; L. monocytogenes, 32; E. coli, 22; S. } \\
\text { dysenteriae, 30; S. typhi, } 27\end{array}$ & [49] \\
\hline $\begin{array}{l}\text { Ziziphus and eucalyptus } \\
\text { leaves }\end{array}$ & Aqueous and ethanol & $\begin{array}{l}\text { B. subtilis, E. coli, S. aureus, P. aeruginosa, } \\
\text { Streptococcus sp. }\end{array}$ & $\begin{array}{c}\text { Extract concentration: } 50-100 \mathrm{mg} / \mathrm{mL} \\
\text { Diameter of inhibition }(\mathrm{mm}): \\
\text { B. subtilis, 11-19; E. coli, 10-16; S. aureus, 8-17; P. aeruginosa, 9-16; } \\
\text { Streptococcus sp., 11-18 }\end{array}$ & [50] \\
\hline Marsilea minuta leaf & Methanol, hexane: methanol & $\begin{array}{l}\text { B. subtilis, Enterococcus faecalis, K. pneumoniae, } P \text {. } \\
\text { aeruginosa }\end{array}$ & MICs: from 125 to $250 \mu \mathrm{g} / \mathrm{mL}$ & [51] \\
\hline $\begin{array}{l}\text { Roselle, rosemary, clove and } \\
\text { thyme }\end{array}$ & Aqueous and ethanol & $\begin{array}{l}\text { B. cereus, S. aureus, E. coli, S. Enteritidis, Vibrio } \\
\text { parahaemolyticus, P. aeruginosa, Candida albicans }\end{array}$ & MICs: from 0.313 to $20 \%(w / v)$ & [52] \\
\hline Pelargonium sidoides DC. & Methanol $(85 \%)$, acetone $(80 \%)$ & $\begin{array}{l}\text { C. perfringens, S. aureus, Shigella flexneri, E. coli } \\
\text { O157, S. Typhimurium, C. albicans }\end{array}$ & $\begin{array}{c}\text { Diameter of inhibition (mm): } \\
\text { C. perfringens, 8-35; S. aureus, 13-29.7; S. flexneri, 13-35.3; E. coli, } \\
\text { 16-36; S. Typhimurium, 11.3-30; C. albicans, 12-30 }\end{array}$ & [53] \\
\hline $\begin{array}{l}15 \text { Mediterranean medicinal } \\
\text { plants }\end{array}$ & Ethanol:water (80:20) & $\begin{array}{l}\text { Camplyobacter coli, E. coli, Salmonella Infantis, B. } \\
\text { cereus, L. monocytogenes, S. aureus }\end{array}$ & $\begin{array}{c}\text { Lowest MIC values (mg/mL): } \\
\text { C. coli, } 0.83 \text { (e.g., bearberry); E. coli, } 1.67 \text { (bearberry); S. Infantis, } 1.67 \\
\text { (bearberry); B. cereus, } 1.67 \text { (e.g., bearberry); L. monocytogenes, } 1.67 \\
\text { (e.g., bearberry); S. aureus, } 0.35 \text { (bearberry) }\end{array}$ & [54] \\
\hline Ginger rhizomes & Aqueous, ethanol, $n$-hexane & $\begin{array}{l}\text { K. pneumoniae, S. typhi, Shigella spp., } P . \\
\text { aeruginosa, E. coli, S. aureus }\end{array}$ & $\begin{array}{c}\text { Extract concentration: } 10 \mu \mathrm{g} / \mathrm{mL} \\
\text { Diameter of inhibition }(\mathrm{mm}): \\
\text { K. pneumoniae, } 0.8-15.4 \text {; S. typhi, 13.2-16.2; Shigella spp., 12.3-17.7; P. } \\
\text { aeruginosa, 12.6-16; E. coli, 14.7-17.2; S. aureus, 13.3-18.3 }\end{array}$ & [55] \\
\hline Ruta chalepensis & Methanol & S. aureus, E. coli, P. aeruginosa & $\begin{array}{c}\text { Extract concentration: } 10 \mathrm{mg} / \text { disk } \\
\text { Diameter of inhibition (mm): } \\
\text { S. aureus, 12.3-16.3; E. coli, 13-17.3; P. aeruginosa, 7.7-17.7 }\end{array}$ & [56] \\
\hline $\begin{array}{c}\text { Syzygium polyanthum } \mathrm{L} \text {. } \\
\text { leaves }\end{array}$ & Ethanol & $\begin{array}{l}\text { E. coli } \mathrm{O} 157: \mathrm{H7}, \text { K. pneumoniae, L. monocytogenes, } \\
\text { Proteus mirabilis, P. aeruginosa, S. Typhimurium, } \\
\text { S. aureus, Vibrio cholerae, V. parahaemolyticus }\end{array}$ & $\begin{array}{c}\text { Extract concentration: } 100 \mu \mathrm{g} / \text { disk } \\
\text { Diameter of inhibition }(\mathrm{mm}): \\
\text { E. coli, } 7 ; \text { K. pneumoniae, } 9.3 ; \text { L. monocytogenes, } 9.6 ; P . \text { mirabilis, } 6.6 ; P \text {. } P \text {. } \\
\text { aeruginosa, } 7 ; \text { S. Typhimurium, } 6.6 ; \text { S. aureus, } 9.3 ; V \text {. cholerae, } 8.3 ; V \text {. } \\
\text { parahaemolyticus, } 6.6 ; \\
\text { MICs: from } 0.63 \text { to } 1.25 \mathrm{mg} / \mathrm{mL} \\
\text { MBCs: from } 0.63 \text { to } 2.5 \mathrm{mg} / \mathrm{mL}\end{array}$ & [57] \\
\hline
\end{tabular}

${ }^{1} \mathrm{MIC}$, minimum inhibitory concentration. ${ }^{2} \mathrm{MBC}$, minimum bactericidal concentration. 
Studies were also done using plant phenolic extracts as natural preservatives in food systems. The work of Sagdic et al. [58], for instance, was oriented towards in situ studies where they tested the antimicrobial activity of grape pomace extracts in beef patties. Samples from five grape varieties were incorporated to beef patties and the growth of Enterobacteriaceae, coliforms, Salmonella, S. aureus, total aerobic mesophilic count, yeast and molds, lactobacilli and micrococci pathogens was studied in different storage periods. Each pomace extract inhibited the microorganisms in a concertation dependent manner. Pathogenic bacteria, yeasts and molds were completely inhibited by 5 and $10 \%$ of the extracts. In another experiment performed in vegetable soup environment, the grape pomace extract showed antibacterial activity in a dose dependent manner against $S$. aureus and E. coli, due to its high proanthocyanidin content [59]. In meat paté, experiments of Hayrapetyan et al. [60] showed that a flavonoid-rich pomegranate (Punica granatum) peel extract could inhibit the growth of L. monocytogenes by $4.1 \log$ at $4{ }^{\circ} \mathrm{C}$ during 46 days, but the inhibitory effect was less effective at higher temperatures (i.e., at 7 and $12{ }^{\circ} \mathrm{C}$ ), demonstrating the influence of temperature on the inhibitory effect. Ahn et al. [61] added grape seed and pine bark extracts and oleoresin rosemary to ground beef and, after cooking, samples were inoculated with strains of foodborne pathogens (E. coli O157:H7, L. monocytogenes, S. Typhimurium and Aeromonas hydrophila). Pine bark extract at $1 \%$ concentration was the most effective against the growth of pathogens after 9 days of storage. Apart from the above studies, there were several experiments on the application of plant phenolic extracts as antimicrobials in various foods (these studies have recently been summarized by Bouarab Chibane et al. [62]).

Individual phenolic compounds of plant extracts have been shown to affect the growth of food-related microorganisms. In the study of García-Ruiz et al. [63], the antimicrobial activity of 18 phenolic compounds, i.e., hydroxycinnamic and hydroxybenzoic acids, stilbenes, flavan-3-ols, flavonols and phenolic alcohols, was evaluated against lactic acid bacteria wine isolates of Oenococcus oeni, Lactobacillus hilgardii and Pediococcus pentosaceus. Among the tested phenolics, the flavonols and stilbenes exhibited the strongest inhibitory effect on bacterial growth. In another experiment, Pastorkova et al. [64] investigated the antimicrobial potential of 15 phenolic compounds (i.e., phenolic acids, stilbenes and flavonoids) naturally occurring in grapes against wine spoilage yeasts and acetic acid bacteria. Pterostilbene, resveratrol and luteolin presented the major inhibitory effects on all tested microorganisms. Phenolic acids, i.e., myricetin, $p$-coumaric and ferulic acids, showed selective antimicrobial activity depending on the yeast and bacteria species tested. Activity of lignans and flavonoids were tested against E. coli, L. monocytogenes, P. aeruginosa, Klebsiella pneumoniae, Enterobacter cloacae, S. aureus and Enterococcus faecalis in the study of Favela-Hernández et al. [65]. Dihydroguaiaretic acid, 4-epi-larreatricin, 3'-Demethoxy-6-O-demethylisoguaiacin and 5,4'-dihydroxy-7-methoxyflavone compounds showed high growth inhibitory potential towards some of the tested strains, with a MIC range from 12.5 to $50 \mu \mathrm{g} / \mathrm{mL}$. MIC values of $500-1000 \mu \mathrm{g} / \mathrm{mL}$ were reported for the 7-hydroxycoumarin (umbelliferone) against S. aureus, methicillin-resistant S. aureus (MRSA), E. coli and P. aeruginosa [66]. Table 3 shows other experiments from the last decade testing antimicrobial activity of individual phenolic compounds. 
Table 3. Antimicrobial activity of individual phenolic compounds, some examples.

\begin{tabular}{|c|c|c|c|c|}
\hline Compounds & Type of Solvent & Target Organism & Antimicrobial Activity & Reference \\
\hline Coumarin, quercetin & $\begin{array}{l}\text { Dissolved in dimethyl sulfoxide } \\
\text { (DMSO) }\end{array}$ & $\begin{array}{l}\text { Escherichia coli, Enterobacter aerogenes, Salmonella } \\
\text { infantis, Salmonella Typhimurium }\end{array}$ & $\begin{array}{c}\text { Coumarin: MIC }{ }^{1}, 0.625-5 \mathrm{mg} / \mathrm{mL} ; \mathrm{MBC}^{2}, \geq 5 \mathrm{mg} / \mathrm{mL} \\
\text { Quercetin: no effect }\end{array}$ & [67] \\
\hline Gallic acid, catechin & Dissolved in DMSO & E. coli & $\begin{array}{c}\text { Inhibition haloes of } 12 \text { and } 14 \mathrm{~mm} \text { in the presence of } 2.5 \text { and } 15 \\
\mathrm{mg} / \text { well gallic acid and catechin, respectively. }\end{array}$ & [68] \\
\hline $\begin{array}{c}\text { Ellagic acid, } \\
\text { quercetin-3-galactoside, } \\
\text { chlorogenic acid, quercetin }\end{array}$ & Tryptic soy broth & Listeria monocytogenes, Salmonella Enteritidis & $\begin{array}{l}\text { Effective concentrations: chlorogenic acid, } 500 \mu \mathrm{g} / \mathrm{mL} \text {; quercetin } \\
\text { and quercetin-3-galactoside, } 200 \mu \mathrm{g} / \mathrm{mL} \text {; ellagic acid, } 44 \mu \mathrm{g} / \mathrm{mL}\end{array}$ & [42] \\
\hline Phloridzin, phloretin & Ethanol & Staphylococcus aureus, E. coli & MIC: S. aureus 0.50 and $0.10 \mathrm{mg} / \mathrm{mL}$, E. coli 1.50 and $0.75 \mathrm{mg} / \mathrm{ml}$ & [43] \\
\hline Thymol & Dissolved in ethanol & L. monocytogenes & MIC: $2 \mathrm{mg} / \mathrm{mL}$ & [69] \\
\hline 11 phenolic compounds & Dissolved in $10 \%$ ethanol & $\begin{array}{c}\text { Bacillus subtilis, Bacillus cereus, L. monocytogenes, } \\
\text { S. aureus, methicillin-resistant } \text { S. aureus, E. coli, } \\
\text { S. Typhimurium, Pseudomonas putida, } \\
\text { Pseudomonas aeruginosa }\end{array}$ & $\begin{array}{c}\text { MICs: from } 125 \text { to } \geq 500 \mu \mathrm{g} / \mathrm{mL} \\
\text { Cinnamic acid and resveratrol, } 125 \mu \mathrm{g} / \mathrm{mL} ; p \text {-coumaric acid, } 250 \\
\mu \mathrm{g} / \mathrm{mL} ; \text { quercetin, } 500 \mu \mathrm{g} / \mathrm{mL} \text { against } B \text {. subtilis, B. cereus, } \\
\text { respectively. Resveratrol, } 250 \text { and } 500 \mu \mathrm{g} / \mathrm{mL} \text { against } P \text {. aeruginosa } \\
\text { and } P \text {. putida, respectively. }\end{array}$ & [3] \\
\hline 17 phenolic compounds & Dissolved in absolute ethanol & $\begin{array}{l}19 \text { S. aureus strains, including enterotoxin } \\
\text { producers }\end{array}$ & $\begin{array}{l}\text { Compound concentration: } 200 \mu \mathrm{g} / \text { disk } \\
\text { Hydroquinone, thymol, carvacrol, butylated hydroxyanisole, octyl } \\
\text { gallate, and tannic acid inhibited the growth of all strains tested. }\end{array}$ & [70] \\
\hline
\end{tabular}

${ }^{1} \mathrm{MIC}$, minimum inhibitory concentration; ${ }^{2} \mathrm{MBC}$, minimum bactericidal concentration. 
The phenolic compounds can express their microbicide effect through different mode of action. These molecules can suppress several microbial virulence factors (e.g., by inhibition of biofilm formation, reduction of host ligand adhesion and neutralization of bacterial toxins), reduce the fluidity of membrane, inhibit the synthesis of nucleic acids and the cell wall or energy metabolism $[29,71]$. In addition, many phenolics could show synergy with antibiotics enhancing their effectiveness and reducing the dose of use [72-74]. The presence and number of hydroxyl groups in phenolic compounds is responsible for their antioxidant properties. In addition, changes in the position of the hydroxyl group could play an important role in the antimicrobial activity [75] and the interactions with cell membrane structures [76]. In case of carvacrol, for instance, presence of the hydroxyl group and the delocalized electron system are thought to be responsible for the cytoplasmic membrane destabilization and the collapse of the proton motive force that finally led to death of Bacillus cereus cells [77]. Phenolic hydroxyl groups can form hydrogen bonds with active site of enzymes inhibiting their catalytic activity [78].

Antimicrobial action of phenolics may vary from molecule to molecule. In the study of Engels et al. [79], gallotannins isolated from mango kernel inhibited the growth of Bacillus subtilis and other foodborne pathogens such as S. aureus and E. coli. The inhibitory effects of gallotannins may be attributed to their iron-complexing properties and ability to interact with proteins and inhibit enzyme activities [79]. At the same time, flavonoids have a series of antibacterial actions with different mechanisms of action, such as inhibition of nucleic acid synthesis [80], induction of cytoplasmic membrane damage [81,82] and inhibition of energy metabolism [83], biofilm formation [3] and bacterial toxin production [84]. The flavonoid catechin can penetrate the lipid bilayers of the membrane resulting in leakage of intramembranous materials and liposome aggregation [85,86]. Moreover, in synergy tests, the catechin-rich fraction of green tea (Camellia sinensis) extracts could reverse the resistance to methicillin in MRSA [87].

On the other hand, it is possible to increase the antimicrobial activity of plant extracts by certain processes. An ecofriendly way is the treatment with carbohydrase enzymes that can hydrolyze the phenolic glycosides improving the antimicrobial potential of the samples. For instance, Pectinase 62L (10 U polygalacturonase equivalent activity) treatment for two hours at $\mathrm{pH} 5.0$ and $37^{\circ} \mathrm{C}$ caused a decrease in the minimum inhibitory concentration (MIC) values of bergamot peel extracts against Salmonella enterica, Pseudomonas putida, E. coli and B. subtilis, compared to the enzyme-free control [88]. The antimicrobial effect against different types of bacteria may depend on the enzyme cocktail(s) used for the treatment as well. In the study of Puupponen-Pimiä et al. [89], different pectinase treatments affected differently the inhibition potential of bilberry extracts against Salmonella and Staphylococcus bacteria. Pectinex Smash, Pectinex BE 3-L and Biopectinase CCM treated samples exhibited the highest antimicrobial activity against the Staphylococcus strains, while Pectinex Ultra SP-L, Pectinex $3 \mathrm{XL}$ and Pectinex BE XXL treatments were superior in case of the Salmonella isolates. For pumpkin and flaxseed extracts, treatment using a mixed cocktail of immobilized Aspergillus oryzae $\alpha$-amylase, and Aspergillus niger $\beta$-glucosidase and $\beta$-glucanase enzymes (in a ratio of 1:1:1) resulted in elevated antimicrobial activity against pathogenic bacteria compared to the enzyme-free sample [90]. Red grape pomace subjected to cellulase-assisted extraction efficiently inhibited the growth of E. coli and S. aureus pathogens in the study of Kabir et al. [31].

\section{Quorum Sensing Systems and Biofilm Formation in Food Related Bacteria}

The quorum sensing system is responsible for the formation of many food deterioration phenotypes [91]. The mechanism regulates important cellular functions such as biofilm formation, sporulation, expression of virulence genes, conjugation, competition, bioluminescence and the production of toxins and pigments. Since the quorum sensing is a density dependent communication mechanism, appearance of the controlled pathological events is related to the density of bacterial cells. The bacterial cells produce and secrete signal molecules, known as autoinducers that accumulate until reaching a sufficient local concentration of bacteria (a quorum) and start a series of population responses, 
including biofilm formation [92]. The autoinducers secreted by the Gram-negative bacteria are mainly $\mathrm{N}$-acylhomoserine lactone (AHL) molecules (autoinducer-1). The autoinducers in Gram-positive bacteria are peptide compounds (i.e., autoinducer peptides, AIP). Furthermore, both Gram-negative and Gram-positive bacteria could secrete autoinducer 2 (AI-2), which are furanosyl borate diester and similar molecules. Other signaling factors, such as $p$-coumaroyl-homoserine lactone [93], unsaturated fatty acids [94] and alkylquinolones are also known [95]. Effective quorum sensing inhibition approaches could be the blocking of the synthesis and the secretion of the autoinducers, the enzymatic degradation of the signal molecules, and the receptor antagonism, in which the antagonist prevents the binding of the signal molecules to response regulator proteins (e.g., to LuxR). However, according to recent investigations, resistance could be developed against certain anti-quorum sensing treatments [96]. Furanones are well-known natural antimicrobials that show destructive activity against the quorum sensing system of both Gram-negative and Gram-positive bacteria [97,98].

Biofilms are microbial communities attached to biotic and abiotic surfaces and embedded in a matrix of extracellular polysaccharides, lipids, proteins and nucleic acids, the so called extracellular polymeric substances (EPS) that are produced by the microbial community itself. Inside the biofilm, the cells display different metabolic activity and physiological, gene expression and morphological patterns compared to the planktonic cells. They become more resistant to environmental adverse factors, such as the lack of nutrients and oxygen and changes in the $\mathrm{pH}$ condition. Biofilm bacteria are less sensitive to the action of antimicrobial agents causing a potential risk in food industry environments [99]. In addition, the antimicrobial substances at subinhibitory concentration can act as environmental signals activating the formation of biofilms [100], thereby, leading to the failure of the drug treatment [101]. However, an effective quorum sensing inhibitor could inhibit the biofilm formation of foodborne pathogenic and spoilage bacteria as well [102-104]. Therefore, in agreement with today's consumer demands, there are food preservative developments focusing on the screen and extensive analysis of natural inhibitory systems.

\section{Anti-Quorum Sensing and Antibiofilm Effects of Plant Phenolics}

Certain plant phenolic substances, including phenol-rich crude extracts, could exhibit anti-biofilm and/or anti-quorum sensing activities [105-107]. The phenolic compounds suppress the bacterial biofilm formation by the inhibition of different regulatory mechanisms without affecting growth: they can block the quorum sensing as mentioned above, reduce the bacterial motility altering their performance [108], decrease the superficial adhesion [109] and inhibit the expression of virulence factors associated with pathogenic behaviors [110,111].

In the study of Vattem et al. [112], the anti-quorum sensing effect of aqueous phenolic extracts from common dietary fruits, herbs and spices was investigated, using the purple pigment violacein producer Chromobacterium violaceum CVO26/CV 31532 bioassay system. The violacein synthesis is under quorum sensing regulation, mediated by AHL autoinducers. Among the fruit extracts tested, raspberry, blueberry and grape samples inhibited the AHL activity, and blueberry had the highest effect on the AHL synthesis. Moreover, blueberry extract was outstanding in the inhibition of quorum sensing related swarming motility in P. aeruginosa and E. coli O157:H7 pathogens. Berry phenolic extracts, namely those from raspberry and cloudberry, were the most effective $C$. violaceum AHL signaling inhibitors in the study of Priha et al. [113]. In addition, the cloudberry extract reduced the biofilm formation of the common brewery contaminant bacterium, Obesumbacterium proteus at the concentrations of 25 and $50 \mathrm{mg} / \mathrm{L}$. A bioactive phenol-rich extract from apple peel was also tested for its anti-quorum sensing effect in the $C$. violaceum agar-diffusion test system by Fratianni et al. [38]. The whole extract exhibited quorum sensing inhibiting activity, which, however, was not detected for the single phenolic compounds of the apple peel. Here, the authors pointed out on possible synergistic or combinatory effects between the molecules in the extract, resulting in anti-quorum sensing activity for the crude sample. In a $C$. violaceum based liquid test, significant inhibition of violacein production was recorded for syringic acid, vanillic acid, (+)-catechin and resveratrol compounds (10 $\mu \mathrm{g} / \mathrm{mL})$, that can 
be found at different concentrations in black grape, apple and pitahaya extracts [3]. The yield of some of these phenolics, obtained via carbohydrase-assisted extraction, showed positive association with the anti-quorum sensing activity of the crude extracts tested. In the same research, all single phenolic compounds tested, i.e., 4-hydroxybenzoic, syringic, gallic, vanillic, cinnamic and $p$-coumaric acids, (+)-catechin, (-)-epicatechin, quercetin, polydatin and resveratrol, inhibited the biofilm formation of $L$. monocytogenes, S. aureus, MRSA, E. coli, S. enterica, P. putida and P. aeruginosa pathogens in vitro, at 100 $\mu \mathrm{g} / \mathrm{mL}$ concentration [3].

In addition, many other studies have addressed the ability of phenolic compounds and different plant extracts to modulate the quorum sensing system and the biofilm formation in foodborne pathogenic and spoilage bacteria. For instance, catechin [114], naringenin [115] and quercetin [116] depicted strong anti-quorum sensing property against P. aeruginosa. Additionally, flavonoid fraction of guava (Psidium guajava L.) leaves extract inhibited the quorum sensing system of $C$. violaceum, and the biofilm formation, pyocyanin production, proteolytic and elastolytic activities and swarming motility in P. aeruginosa PAO1 [117]. It was shown that the quercetin and quercetin-3-O-arabinoside components of the flavonoid extract were responsible for the anti-quorum sensing activity.

There were several investigations concerning the inhibition of pathogenic E. coli biofilms by phenolics. In the study of Lee et al. [118], the flavonoid phloretin, a major compound in apple and strawberry extracts, has inhibited the formation of E. coli O157:H7 biofilms without affecting the growth of planktonic cells. Two furocoumarins isolated from grapefruit juice, bergamottin and dihydroxybergamottin, suppressed the biofilm formation of E. coli O157:H7 in a range of 71.9 and $58.3 \%$, respectively [119]. Furthermore, naringenin, quercetin, sinensetin and apigenin were effective quorum sensing antagonists and biofilm suppressors in E. coli O157:H7 strain [120]. For non-O157 Shiga toxin producing E. coli strains, Sheng et al. [121] found that the grape seed extract inhibited well the quorum sensing system.

Many phenolic acids proved to be effective against $S$. aureus biofilms as well. With this context, the gallic [122], ginkgolic [123], ellagic [124] and rosmarinic acids [125] have been found to be promising inhibitors in the research of the past decade. The phenolic glycoside compound, 1,2,3,4,6-penta-O-galloyl- $\beta$-D-glucopyranose, purified from Eustigma oblongifolium extract, inhibited the formation of $S$. aureus biofilms by blocking the synthesis of cell-to-cell adhesion compounds, thereby, preventing the primary attachment to solid surfaces [126]. It was also shown that methanol extract from pomegranate, rich in ellagic acid, inhibited the biofilm formation of S. aureus, MRSA, E. coli and C. albicans [124]. Red wines, extensively recognized for their high flavonoid (e.g., quercetin, kaempferol, apigenin, chrysin, fisetin and luteolin) and stilbenoid (e.g., trans-resveratrol) content have proven to be potent inhibitor of $S$. aureus biofilms [127]. Among the compounds tested, the quercetin exhibited the highest biofilm inhibitory potential. In addition, phenolic extracts from muscadine grape were also able to inhibit and eradicate the S. aureus biofilm in the study of $\mathrm{Xu}$ et al. [128]. A summary of some recently published researches about antibiofilm activity of plant extracts against food-related microorganisms is presented in Table 4. 
Table 4. Antibiofilm activity of plant extracts against food pathogen microorganisms, examples from recent studies.

\begin{tabular}{|c|c|c|c|c|}
\hline Source/Residue & $\begin{array}{l}\text { Solvent of } \\
\text { Extraction }\end{array}$ & Target Biofilm & Percent Biofilm Inhibition & Reference \\
\hline $\begin{array}{l}\text { Black Cardamom } \\
\text { (Amomum tsao-ko) } \\
\text { extract }\end{array}$ & $80 \%$ ethanol & $\begin{array}{c}\text { Staphylococcus aureus, Salmonella } \\
\text { Typhimurium, Pseudomonas aeruginosa }\end{array}$ & $45.2-51.9 \%$ (4 mg/mL cc.) & [129] \\
\hline $\begin{array}{l}\text { Propolis and bud } \\
\text { poplar resins }\end{array}$ & $85 \%$ ethanol & P. aeruginosa & $50-60 \%(100 \mu \mathrm{g} / \mathrm{mL}$ cc. $)$ & [130] \\
\hline Butia odorata extract & acetone & S. aureus & 99.9\% (11.4-22.8 mg/mL cc.) & [131] \\
\hline Onion extracts & methanol & P. aeruginosa, S. aureus & $27.3-61.5 \%(50 \mu \mathrm{g} / \mathrm{mL} \mathrm{cc})$. & [132] \\
\hline Olive leaves & methanol & $\begin{array}{c}\text { P. aeruginosa, methicillin-resistant } \\
\text { Staphylococcus aureus (MRSA), S. aureus, } \\
\text { Bacillus subtilis, Escherichia coli, } \\
\text { Enterococcus faecalis, Candida albicans }\end{array}$ & $29.3-98 \%(32-512 \mu \mathrm{g} / \mathrm{mL}$ сc.) & [133] \\
\hline $\begin{array}{l}\text { Populus nigra and } \\
\text { Populus alba bud } \\
\text { extracts }\end{array}$ & methanol & MRSA, S. aureus & $\begin{array}{l}>70 \% \text { for P. nigra, }>50 \% \text { for } \\
\text { P. alba }\end{array}$ & [134] \\
\hline $\begin{array}{l}\text { Opuntia ficus-indica } \\
\text { cladodes }\end{array}$ & $80 \%$ methanol & S. aureus & $71-85 \%$ (1-1.5 mg/mL cc.) & [135] \\
\hline $\begin{array}{l}\text { Eugenia and } \\
\text { Syzygium leaf } \\
\text { extracts }\end{array}$ & acetone & $\begin{array}{c}\text { P. aeruginosa, S. Typhimurium, S. aureus, } \\
\text { E. faecalis, E. coli, Bacillus cereus }\end{array}$ & $\begin{array}{l}>50 \% \text { for several samples } \\
\quad(1 \mathrm{mg} / \mathrm{mL} \mathrm{cc} .)\end{array}$ & [136] \\
\hline $\begin{array}{l}\text { Potentilla visianii } \\
\text { extracts }\end{array}$ & $\begin{array}{l}\text { methanol, ethyl } \\
\text { acetate }\end{array}$ & $\begin{array}{c}\text { Salmonella enterica, E. coli, S. aureus, } \\
\text { B. subtilis }\end{array}$ & $>50 \%(1.1-10 \mathrm{mg} / \mathrm{mL} \mathrm{cc})$. & [137] \\
\hline $\begin{array}{c}\text { Gentiana asclepiadea } \\
\text { extracts }\end{array}$ & $\begin{array}{l}\text { water, ethanol, } \\
\text { acetone }\end{array}$ & S. aureus, P. aeruginosa, Proteus mirabilis & $>50 \%(2.1-37 \mathrm{mg} / \mathrm{mL} \mathrm{cc})$. & [138] \\
\hline
\end{tabular}

\section{Anti-Enterotoxin Effect of Plant Phenolics}

Many phenolic compounds and extracts even at concentrations below the MIC can inhibit the production and/or the activity of bacterial enterotoxins [139]. These anti-enterotoxin properties are being intensively tested for foodborne pathogens, especially in case of $S$. aureus. The staphylococcal enterotoxins and enterotoxin-like molecules are low-molecular weight proteins with a globular structure. They have superantigenic activity and are varied in their emetic potential [140]. Among them, the enterotoxin A is responsible for most staphylococcal food poisoning outbreaks [141]. Phenolic compounds can affect the enterotoxin production through several mode of action, including translation and/or transcription inhibition, disruption of secretory mechanisms, inhibition of quorum sensing regulatory systems, and toxin inactivation [142,143]. Various plant derived phenolic substances have been described as effective inhibitors of the staphylococcal enterotoxin production and activity (Table 5). 
Table 5. Anti-staphylococcal enterotoxin effect of plant phenolic extracts and compounds.

\begin{tabular}{|c|c|c|c|}
\hline $\begin{array}{c}\text { Phenolic } \\
\text { Extract/Compound }\end{array}$ & $\begin{array}{c}\text { Target Staphylococcal } \\
\text { Enterotoxin }\end{array}$ & Anti-Enterotoxin Activity & Reference \\
\hline Licochalcone A & $\begin{array}{c}\text { Enterotoxins A (SEA) } \\
\text { and B (SEB) }\end{array}$ & $\begin{array}{c}\text { Effective concentration: } 0.25 \mathrm{mg} / \mathrm{mL} \\
\text { Secretion inhibition; Inhibition of regulatory gene (agrA) } \\
\text { transcription }\end{array}$ & [144] \\
\hline Carvacrol and thymol & Not specified & Total inhibition of secretion at 0.3 and $0.15 \mu \mathrm{L} / \mathrm{mL}$ concentrations & [145] \\
\hline $\begin{array}{l}\text { Cinnamaldehyde, } \\
\text { citronellol, eugenol, } \\
\text { geraniol and terpineol }\end{array}$ & $\begin{array}{l}\text { SEA, SEB, Enterotoxins C } \\
\text { (SEC) and D (SED) }\end{array}$ & $\begin{array}{l}\text { Concentrations: } 120-1300 \mu \mathrm{g} / \mathrm{mL} \\
\text { SEA: eugenol, citronellol and geraniol reduced the production; SEB: } \\
\text { terpineol and eugenol inhibited the production; SEC: most sensitive } \\
\text { to the phenolics; SED: no inhibition }\end{array}$ & [142] \\
\hline 16 phenolic compounds & SEA & $\begin{array}{l}\text { Inhibition of SEA protein level (penta-galloyl-glucose, corilagin, } \\
\text { punicalagin, castalagin and procyanidin B2 at } 0.25 \mathrm{mg} / \mathrm{mL} \text { ) and } \\
\text { activity (penta-galloyl-glucose, tannic acid, persimmon tannin, } \\
\text { corilagin, punicalagin, eugeniin, sanguiin H-6, geraniin, } \\
\text { pedunculagin and castalagin, } 3-25 \mu \mathrm{g} / \mathrm{mL} \text { ), interaction with SEA } \\
\text { (eugeniin, castalagin, punicalagin, pedunculagin, corilagin, } \\
\text { geraniin, penta-galloyl-glucose and sanguiin } \mathrm{H}-6 \text { at } 0.25 \mathrm{mg} / \mathrm{mL} \text { ) }\end{array}$ & [146] \\
\hline Tea catechin & Enterotoxin I (SEI) & Inhibition of sei gene expression at $0.4 \mathrm{~g} / \mathrm{L}$ concentration & [148] \\
\hline $\begin{array}{l}\text { Apple juice and apple } \\
\text { polyphenols }\end{array}$ & SEA & $\begin{array}{c}\text { Activity inhibition: } \\
\text { Red Delicious at } 0.025 \% \\
\text { Apple Poly phenol-rich extract at } 0.06-0.3 \%\end{array}$ & [149] \\
\hline $\begin{array}{l}\text { Witch-hazel and green } \\
\text { tea extracts }\end{array}$ & SEA & $\begin{array}{c}\text { Witch-hazel: inhibition of SEA production at } 0.015 \mathrm{mg} / \mathrm{mL} \mathrm{GAE} \\
\text { concentration } \\
\text { Green tea: no effect }\end{array}$ & [143] \\
\hline
\end{tabular}

Activity of phenolics on AB-type protein toxins, e.g., cholera toxin, Shiga toxins, E. coli heat-labile toxin, $P$. aeruginosa exotoxin A, has also been extensively studied. These toxins consist of an A catalytic subunit and a B cell-binding subunit. Grape extracts inhibited the cholera intoxication in cultured cells and intestinal loops through various actions, including the elimination of the pre-bound toxin from the cell surfaces, and disruption of the unfolding, transport and catalytic activities of the dissociated A subunit [152]. In a later study, the function of 20 individual phenolic constituents of grape extracts in cholera toxin inhibition was assessed [153]. Among others, inhibitory functions affecting the toxin binding and the enzyme activity have been associated with the mode of action of individual phenolic compounds. For instance, resveratrol disrupted the toxin internalization and activity, epigallocatechin gallate and procyanidin blocked the toxin binding and occupied the binding sites, and kaempferol and quercitrin could directly inhibit the activity of the catalytic subunit. Grape seed and grape pomace extracts effectively disrupted the action of the Shiga toxin 1 and 2, and the heat-labile toxin as well $[152,154]$.

\section{Conclusions}

Many phenolic compounds and phenol-rich plant extracts have promising activity to inhibit the growth of both the planktonic form and the biofilms of food related pathogens. Investigation of this property is particularly important as bacterial biofilm layers are commonly formed on foods and/or food contact surfaces, resulting in a microbial community more resistant to the traditional disinfectant agents. Moreover, their inhibitory properties against the production and activity of bacterial enterotoxins can make many plant phenolics effective in preventing food poisoning symptoms. Plant phenolics could have anti-quorum sensing activity as well. The quorum sensing mechanism regulates the biofilm formation and toxin production of pathogenic bacteria; therefore, discovery and analysis of substances suppressing this system has also occupied a prominent field in the current researches. In conclusion, the summarized studies emphasize not only the importance of plant phenolic extracts as sources 
of natural preservatives but provide alternatives for ecofriendly utilization of some agro- and food industrial byproducts and enzyme aided extraction processes as well.

Author Contributions: Conceptualization, M.T., J.K. and C.V.; writing—original draft preparation, M.T., E.B.K., C.Z. and A.K.; writing-review and editing, M.T., T.P., J.K. and C.V. All authors have read and agreed to the published version of the manuscript.

Funding: This work was supported by the Hungarian Government and the European Union within the frames of the Széchenyi 2020 Programme through grant EFOP-3.6.1-16-2016-00008. M.T. was supported by the grants János Bolyai Research Scholarship of the Hungarian Academy of Sciences and the UNKP-19-4 New National Excellence Program of the Ministry for Innovation and Technology. T.P. is supported by the grants LP2016-8/2016 and by the FIKP program (TUDFO/4738-1/2019 ITM) of the Ministry of Human Capacities.

Acknowledgments: The authors thank Mónika Varga for her editing work on the chemical structure of phenolics.

Conflicts of Interest: The authors declare no conflict of interest.

\section{References}

1. Del Rio, D.; Rodriguez-Mateos, A.; Spencer, J.P.E.; Tognolini, M.; Borges, G.; Crozier, A. Dietary (poly) phenolics in human health: Structures, bioavailability, and evidence of protective effects against chronic diseases. Antioxid. Redox Signal. 2013, 18, 1818-1892. [CrossRef]

2. Gyawali, R.; Ibrahim, S.A. Natural products as antimicrobial agents. Food Control 2014, 46, 412-429. [CrossRef]

3. Zambrano, C.; Kerekes, E.B.; Kotogán, A.; Papp, T.; Vágvölgyi, C.; Krisch, J.; Takó, M. Antimicrobial activity of grape, apple and pitahaya residue extracts after carbohydrase treatment against food-related bacteria. LWT Food Sci. Technol. 2019, 100, 416-425. [CrossRef]

4. Nazzaro, F.; Fratianni, F.; Coppola, R. Quorum sensing and phytochemicals. Int. J. Mol. Sci. 2013, 14, 12607-12619. [CrossRef] [PubMed]

5. Kowalska, H.; Czajkowska, K.; Cichowska, J.; Lenart, A. What's new in biopotential of fruit and vegetable by-products applied in the food processing industry. Trends Food Sci. Technol. 2017, 67, 150-159. [CrossRef]

6. Aires, A. Phenolics in foods: Extraction, analysis and measurements. In Phenolic Compounds—Natural Sources, Importance and Applications; Soto-Hernandez, M., Palma-Tenango, M., Del Rosario Garcia-Mateos, M., Eds.; IntechOpen: London, UK, 2017; pp. 61-88.

7. Xu, D.-P.; Li, Y.; Meng, X.; Zhou, T.; Zhou, Y.; Zheng, J.; Zhang, J.-J.; Li, H.-B. Natural antioxidants in foods and medicinal plants: Extraction, assessment and resources. Int. J. Mol. Sci. 2017, 18, 96. [CrossRef] [PubMed]

8. Zambrano, C.; Kotogán, A.; Bencsik, O.; Papp, T.; Vágvölgyi, C.; Mondal, K.C.; Krisch, J.; Takó, M. Mobilization of phenolic antioxidants from grape, apple and pitahaya residues via solid state fungal fermentation and carbohydrase treatment. LWT Food Sci. Technol. 2018, 89, 457-465. [CrossRef]

9. Ngwoke, K.G.; Odimegwu, D.C.; Esimone, C.O. Antimicrobial natural products. In Science Against Microbial Pathogens: Communicating Current Research and Technology Advances; Méndez-Vilas, A., Ed.; FORMATEX: Badajoz, Spain, 2011; pp. 1011-1026.

10. Stojković, D.; Petrović, J.; Soković, M.; Glamočlija, J.; Kukić-Marković, J.; Petrović, S. In situ antioxidant and antimicrobial activities of naturally occurring caffeic acid, $p$-coumaric acid and rutin, using food systems. J. Sci. Food Agric. 2013, 93, 3205-3208. [CrossRef]

11. Papuc, C.; Goran, G.V.; Predescu, C.N.; Nicorescu, V.; Stefan, G. Plant polyphenols as antioxidant and antibacterial agents for shelf-life extension of meat and meat products: Classification, structures, sources, and action mechanisms. Compr. Rev. Food Sci. Food Saf. 2017, 16, 1243-1268. [CrossRef]

12. Shahidi, F.; Ambigaipalan, P. Phenolics and polyphenolics in foods, beverages and spices: Antioxidant activity and health effects-A review. J. Funct. Foods 2015, 18, 820-897. [CrossRef]

13. Bintsis, T. Foodborne pathogens. AIMS Microbiol. 2017, 3, 529-563. [CrossRef] [PubMed]

14. Lai, C.-K.; Chen, Y.-A.; Lin, C.-J.; Lin, H.-J.; Kao, M.-C.; Huang, M.-Z.; Lin, Y.-H.; Chiang-Ni, C.; Chen, C.-J.; Lo, U.-G.; et al. Molecular mechanisms and potential clinical applications of Campylobacter jejuni cytolethal distending toxin. Front. Cell. Infect. Microbiol. 2016, 6, 9. [CrossRef] [PubMed]

15. Heredia, N.; García, S. Animals as sources of food-borne pathogens: A review. Anim. Nutr. 2018, 4, $250-255$. [CrossRef] [PubMed]

16. Hamon, M.A.; Ribet, D.; Stavru, F.; Cossart, P. Listeriolysin O: The Swiss army knife of Listeria. Trends Microbiol. 2012, 20, 360-368. [CrossRef] 
17. King, J.C.; Black, R.E.; Doyle, M.P.; Fritsche, K.L.; Halbrook, B.H.; Levander, O.A.; Meydani, S.N.; Walker, W.A.; Woteki, C.E. Foodborne illnesses and nutritional status: A statement from an American Society for Nutritional Sciences Working Group. J. Nutr. 2000, 130, 2613-2617. [CrossRef]

18. Shallcross, L.J.; Davies, D.S.C. Antibiotic overuse: A key driver of antimicrobial resistance. Br. J. Gen. Pract. 2014, 64, 604-605. [CrossRef]

19. Hashempour-Baltork, F.; Hosseini, H.; Shojaee-Aliabadi, S.; Torbati, M.; Alizadeh, A.M.; Alizadeh, M. Drug resistance and the prevention strategies in food borne bacteria: An update review. Adv. Pharm. Bull. 2019, 9, 335-347. [CrossRef]

20. Rawat, S. Food spoilage: Microorganisms and their prevention. Asian J. Plant Sci. Res. 2015, 5, 47-56.

21. Sperber, W.H. Introduction to the microbiological spoilage of foods and beverages. In Compendium of the Microbiological Spoilage of Foods and Beverages; Sperber, W.H., Doyle, M.P., Eds.; Springer: New York, NY, USA, 2009; pp. 1-40.

22. Garnier, L.; Valence, F.; Mounier, J. Diversity and control of spoilage fungi in dairy products: An update. Microorganisms 2017, 5, 42. [CrossRef]

23. Mandal, P.K.; Biswas, A.K.; Choi, K.; Pal, U.K. Methods for rapid detection of foodborne pathogens: An overview. Am. J. Food Technol. 2011, 6, 87-102. [CrossRef]

24. Jadhav, S.R.; Shah, R.M.; Karpe, A.V.; Morrison, P.D.; Kouremenos, K.; Beale, D.J.; Palombo, E.A. Detection of foodborne pathogens using proteomics and metabolomics-based approaches. Front. Microbiol. 2018, 9, 3132. [CrossRef] [PubMed]

25. Fletcher, B.; Mullane, K.; Platts, P.; Todd, E.; Power, A.; Roberts, J.; Chapman, J.; Cozzolino, D.; Chandra, S. Advances in meat spoilage detection: A short focus on rapid methods and technologies. CYTA J. Food 2018, 16, 1037-1044. [CrossRef]

26. Daglia, M. Polyphenols as antimicrobial agents. Curr. Opin. Biotechnol. 2012, 23, 174-181. [CrossRef] [PubMed]

27. Schmidt, T.J.; Khalid, S.A.; Romanha, A.J.; Alves, T.M.A.; Biavatti, M.W.; Brun, R.; Da Costa, F.B.; De Castro, S.L.; Ferreira, V.F.; De Lacerda, M.V.G.; et al. The potential of secondary metabolites from plants as drugs or leads against protozoan neglected diseases-part II. Curr. Med. Chem. 2012, 19, 2176-2228. [CrossRef]

28. Li, A.-N.; Li, S.; Zhang, Y.-J.; Xu, X.-R.; Chen, Y.-M.; Li, H.-B. Resources and biological activities of natural polyphenols. Nutrients 2014, 6, 6020-6047. [CrossRef]

29. Górniak, I.; Bartoszewski, R.; Króliczewski, J. Comprehensive review of antimicrobial activities of plant flavonoids. Phytochem. Rev. 2019, 18, 241-272. [CrossRef]

30. Özkan, G.; Sagdiç, O.; Göktürk Baydar, N.; Kurumahmutoglu, Z. Antibacterial activities and total phenolic contents of grape pomace extracts. J. Sci. Food Agric. 2004, 84, 1807-1811. [CrossRef]

31. Kabir, F.; Sultana, M.S.; Kurnianta, H. Antimicrobial activities of grape (Vitis vinifera L.) pomace polyphenols as a source of naturally occurring bioactive components. Afr. J. Biotechnol. 2015, 14, 2157-2161.

32. Jayaprakasha, G.K.; Selvi, T.; Sakariah, K.K. Antibacterial and antioxidant activities of grape (Vitis vinifera) seed extracts. Food Res. Int. 2003, 36, 117-122. [CrossRef]

33. Silván, J.M.; Mingo, E.; Hidalgo, M.; De Pascual-Teresa, S.; Carrascosa, A.V.; Martinez-Rodriguez, A.J. Antibacterial activity of a grape seed extract and its fractions against Campylobacter spp. Food Control 2013, 29, 25-31. [CrossRef]

34. Levy, J.; Boyer, R.R.; Neilson, A.P.; O’Keefe, S.F.; Chu, H.S.S.; Williams, R.C.; Dorenkott, M.R.; Goodrich, K.M. Evaluation of peanut skin and grape seed extracts to inhibit growth of foodborne pathogens. Food Sci. Nutr. 2017, 5, 1130-1138. [CrossRef] [PubMed]

35. Tenore, G.C.; Novellino, E.; Basile, A. Nutraceutical potential and antioxidant benefits of red pitaya (Hylocereus polyrhizus) extracts. J. Funct. Foods 2012, 4, 129-136. [CrossRef]

36. Yong, Y.Y.; Dykes, G.; Lee, S.M.; Choo, W.S. Comparative study of betacyanin profile and antimicrobial activity of red pitahaya (Hylocereus polyrhizus) and red spinach (Amaranthus dubius). Plant Food. Hum. Nutr. 2017, 72, 41-47. [CrossRef] [PubMed]

37. Tseng, A.; Zhao, Y. Effect of different drying methods and storage time on the retention of bioactive compounds and antibacterial activity of wine grape pomace (Pinot Noir and Merlot). J. Food Sci. 2012, 77, H192-H201. [CrossRef] 
38. Fratianni, F.; Coppola, R.; Nazzaro, F. Phenolic composition and antimicrobial and antiquorum sensing activity of an ethanolic extract of peels from the apple cultivar annurca. J. Med. Food 2011, 14, 957-963. [CrossRef]

39. Xu, Y.; Burton, S.; Kim, C.; Sismour, E. Phenolic compounds, antioxidant, and antibacterial properties of pomace extracts from four Virginia-grown grape varieties. Food Sci. Nutr. 2016, 4, 125-133. [CrossRef]

40. Usha, M.; Ragini, S.; Naqvi, S.M.A. Antibacterial activity of acetone and ethanol extracts of cinnamon (Cinnamomum zeylanicum) and Ajowan (Trachyspermum ammi) on four food spoilage bacteria. Int. Res. J. Biol. Sci. 2012, 1, 7-11.

41. Salaheen, S.; Nguyen, C.; Hewes, D.; Biswas, D. Cheap extraction of antibacterial compounds of berry pomace and their mode of action against the pathogen Campylobacter jejuni. Food Control 2014, 46, 174-181. [CrossRef]

42. Shen, X.; Sun, X.; Xie, Q.; Liu, H.; Zhao, Y.; Pan, Y.; Hwang, C.-A.; Wu, V.C.H. Antimicrobial effect of blueberry (Vaccinium corymbosum L.) extracts against the growth of Listeria monocytogenes and Salmonella Enteritidis. Food Control 2014, 35, 159-165. [CrossRef]

43. Zhang, T.; Wei, X.; Miao, Z.; Hassan, H.; Song, Y.; Fan, M. Screening for antioxidant and antibacterial activities of phenolics from Golden Delicious apple pomace. Chem. Cent. J. 2016, 10, 47. [CrossRef]

44. Ju, J.; Xie, Y.; Guo, Y.; Cheng, Y.; Qian, H.; Yao, W. Antibacterial activities of bayberry extract on foodborne pathogens and identification of its active components. Food Agric. Immunol. 2019, 30, 385-397. [CrossRef]

45. Luchian, C.E.; Cotea, V.V.; Vlase, L.; Toiu, A.M.; Colibaba, L.C.; Răschip, I.E.; Nadăş, G.; Gheldiu, A.M.; Tuchiluş, C.; Rotaru, L. Antioxidant and antimicrobial effects of grape pomace extracts. BIO Web Conf. 2019, 15, 04006. [CrossRef]

46. Radovanović, V.N.; Andjelković, M.; Arsić, B.; Radovanović, A.; Gojković-Bukarica, L. Cost-effective ultrasonic extraction of bioactive polyphenols from vine and wine waste in Serbia. S. Afr. J. Enol. Vitic. 2019, 40, 172-180. [CrossRef]

47. Olejar, K.J.; Ricci, A.; Swift, S.; Zujovic, Z.; Gordon, K.C.; Fedrizzi, B.; Versari, A.; Kilmartin, P.A. Characterization of an antioxidant and antimicrobial extract from cool climate, white grape marc. Antioxidants 2019, 8, 232. [CrossRef] [PubMed]

48. Raphaelli, C.O.; Dannenberg, G.; Dalmazo, G.O.; Pereira, E.S.; Radünz, M.; Vizzotto, M.; Fiorentini, A.M.; Gandra, E.A.; Nora, L. Antibacterial and antioxidant properties of phenolic-rich extracts from apple (Malus domestica cv. Gala). Int. Food Res. J. 2019, 26, 1133-1142.

49. Mahboubi, A.; Asgarpanah, J.; Sadaghiyani, P.N.; Faizi, M. Total phenolic and flavonoid content and antibacterial activity of Punica granatum L. var. pleniflora flowers (Golnar) against bacterial strains causing foodborne diseases. BMC Complement. Altern. Med. 2015, 15, 366. [CrossRef]

50. Al-Manhel, A.J.; Niamah, A.K. Effect of aqueous and alcoholic plant extracts on inhibition of some types of microbes and causing spoilage of food. J. Nutr. Food. Sci. 2015, S5, 104-109. [CrossRef]

51. Arokiyaraj, S.; Bharanidharan, R.; Agastian, P.; Shin, H. Chemical composition, antioxidant activity and antibacterial mechanism of action from Marsilea minuta leaf hexane: Methanol extract. Chem. Cent. J. 2018, 12, 105. [CrossRef]

52. Gonelimali, F.D.; Lin, J.; Miao, W.; Xuan, J.; Charles, F.; Chen, M.; Hatab, S.R. Antimicrobial properties and mechanism of action of some plant extracts against food pathogens and spoilage microorganisms. Front. Microbiol. 2018, 9, 1639. [CrossRef]

53. Ibrahim, M.M.; El Ghani, S.A.; El-Moez, S.I.A. Phytochemical analysis and antimicrobial activities of different callus extracts of Pelargonium sidoides DC. against food borne pathogenic bacteria. J. Appl. Pharm. Sci. 2018, 8, 109-118.

54. Generalić Mekinić, I.; Skroza, D.; Ljubenkov, I.; Katalinić, V.; Šimat, V. Antioxidant and antimicrobial potential of phenolic metabolites from traditionally used Mediterranean herbs and spices. Foods 2019, 8, 579. [CrossRef]

55. Nas, F.S.; Ali, M.; Ahmad, A.M. In vitro antibacterial activity of different extracts of Zingiber officinale against bacterial isolates responsible for food spoilage. SOA Arch. Pharm. Pharmacol. 2018, 1, 001.

56. Ouerghemmi, I.; Rebey, I.B.; Rahali, F.Z.; Bourgou, S.; Pistelli, L.; Ksouri, R.; Marzouk, B.; Tounsi, M.S. Antioxidant and antimicrobial phenolic compounds from extracts of cultivated and wild-grown Tunisian Ruta chalepensis. J. Food Drug Anal. 2017, 25, 350-359. [CrossRef] 
57. Ramli, S.; Radu, S.; Shaari, K.; Rukayadi, Y. Antibacterial activity of ethanolic extract of Syzygium polyanthum L. (Salam) leaves against foodborne pathogens and application as food sanitizer. BioMed Res. Int. 2017, 2017, 9024246. [CrossRef]

58. Sagdic, O.; Ozturk, I.; Yilmaz, M.T.; Yetim, H. Effect of grape pomace extracts obtained from different grape varieties on microbial quality of beef patty. J. Food Sci. 2011, 76, M515-M521. [CrossRef]

59. Sagdic, O.; Ozturk, I.; Kisi, O. Modeling antimicrobial effect of different grape pomace and extracts on $S$. aureus and E. coli in vegetable soup using artificial neural network and fuzzy logic system. Expert Syst. Appl. 2012, 39, 6792-6798. [CrossRef]

60. Hayrapetyan, H.; Hazeleger, W.C.; Beumer, R.R. Inhibition of Listeria monocytogenes by pomegranate (Punica granatum) peel extract in meat paté at different temperatures. Food Control 2012, 23, 66-72. [CrossRef]

61. Ahn, J.; Grün, I.U.; Mustapha, A. Effects of plant extracts on microbial growth, color change, and lipid oxidation in cooked beef. Food Microbiol. 2007, 24, 7-14. [CrossRef]

62. Bouarab Chibane, L.; Degraeve, P.; Ferhout, H.; Bouajila, J.; Oulahal, N. Plant antimicrobial polyphenols as potential natural food preservatives. J. Sci. Food Agric. 2019, 99, 1457-1474. [CrossRef]

63. García-Ruiz, A.; Moreno-Arribas, M.V.; Martín-Álvarez, P.J.; Bartolomé, B. Comparative study of the inhibitory effects of wine polyphenols on the growth of enological lactic acid bacteria. Int. J. Food Microbiol. 2011, 145, 426-431. [CrossRef]

64. Pastorkova, E.; Zakova, T.; Landa, P.; Novakova, J.; Vadlejch, J.; Kokoska, L. Growth inhibitory effect of grape phenolics against wine spoilage yeasts and acetic acid bacteria. Int. J. Food Microbiol. 2013, 161, $209-213$. [CrossRef] [PubMed]

65. Favela-Hernández, J.M.J.; García, A.; Garza-González, E.; Rivas-Galindo, V.M.; Camacho-Corona, M.R. Antibacterial and antimycobacterial lignans and flavonoids from Larrea tridentata. Phytother. Res. 2012, 26, 1957-1960. [CrossRef] [PubMed]

66. Rehman, S.-U.; Khan, R.; Bhat, K.A.; Raja, A.F.; Shawl, A.S.; Alam, M.S. Isolation, characterisation and antibacterial activity studies of coumarins from Rhododendron lepidotum Wall. ex G. Don, Ericaceae. Rev. Bras. Farmacogn. 2010, 20, 886-890. [CrossRef]

67. Nitiema, L.W.; Savadogo, A.; Simpore, J.; Dianou, D.; Traore, A.S. In vitro antimicrobial activity of some phenolic compounds (coumarin and quercetin) against gastroenteritis bacterial strains. Int. J. Microbiol. Res. 2012, 3, 183-187.

68. Díaz-Gómez, R.; Toledo-Araya, H.; López-Solís, R.; Obreque-Slier, E. Combined effect of gallic acid and catechin against Escherichia coli. LWT Food Sci. Technol. 2014, 59, 896-900. [CrossRef]

69. Kerekes, E.B.; Vidács, A.; Jenei Török, J.; Gömöri, C.; Petkovits, T.; Chandrasekaran, M.; Kadaikunnan, S.; Alharbi, N.S.; Vágvölgyi, C.; Krisch, J. Anti-listerial effect of selected essential oils and thymol. Acta Biol. Hung. 2016, 67, 333-343. [CrossRef]

70. Rúa, J.; Fernandez-Alvarez, L.; Gutierrez-Larrainzar, M.; Del Valle, P.; De Arriaga, D.; García-Armesto, M.R. Screening of phenolic antioxidants for their inhibitory activity against foodborne Staphylococcus aureus strains. Foodborne Pathog. Dis. 2010, 7, 695-705. [CrossRef]

71. Quideau, S.; Deffieux, D.; Douat-Casassus, C.; Pouységu, L. Plant polyphenols: Chemical properties, biological activities, and synthesis. Angew. Chem. Int. Ed. Engl. 2011, 50, 586-621. [CrossRef]

72. Sanhueza, L.; Melo, R.; Montero, R.; Maisey, K.; Mendoza, L.; Wilkens, M. Synergistic interactions between phenolic compounds identified in grape pomace extract with antibiotics of different classes against Staphylococcus aureus and Escherichia coli. PLoS ONE 2017, 12, e0172273. [CrossRef]

73. Stefanović, O.D. Synergistic activity of antibiotics and bioactive plant extracts: A study against Gram-positive and Gram-negative bacteria. In Bacterial Pathogenesis and Antibacterial Control; Kırmusaoğlu, S., Ed.; IntechOpen: London, UK, 2018; pp. 23-48.

74. Miklasińska-Majdanik, M.; Kępa, M.; Wojtyczka, R.D.; Idzik, D.; Wąsik, T.J. Phenolic compounds diminish antibiotic resistance of Staphylococcus aureus clinical strains. Int. J. Environ. Res. Public Health 2018, 15, 2321. [CrossRef]

75. Figueiredo, A.R.; Campos, F.; De Freitas, V.; Hogg, T.; Couto, J.A. Effect of phenolic aldehydes and flavonoids on growth and inactivation of Oenococcus oeni and Lactobacillus hilgardii. Food Microbiol. 2008, 25, 105-112. [CrossRef] 
76. Oteiza, P.I.; Erlejman, A.G.; Verstraeten, S.V.; Keen, C.L.; Fraga, C.G. Flavonoid-membrane interactions: A protective role of flavonoids at the membrane surface? Clin. Dev. Immunol. 2005, 12, 19-25. [CrossRef] [PubMed]

77. Ultee, A.; Bennik, M.H.J.; Moezelaar, R. The phenolic hydroxyl group of carvacrol is essential for action against the food-borne pathogen Bacillus cereus. Appl. Environ. Microbiol. 2002, 68, 1561-1568. [CrossRef] [PubMed]

78. Jeong, K.-W.; Lee, J.-Y.; Kang, D.-I.; Lee, J.-U.; Shin, S.Y.; Kim, Y. Screening of flavonoids as candidate antibiotics against Enterococcus faecalis. J. Nat. Prod. 2009, 72, 719-724. [CrossRef]

79. Engels, C.; Knödler, M.; Zhao, Y.-Y.; Carle, R.; Gänzle, M.G.; Schieber, A. Antimicrobial activity of gallotannins isolated from mango (Mangifera indica L.) kernels. J. Agric. Food Chem. 2009, 57, 7712-7718. [CrossRef]

80. Wu, T.; Zang, X.; He, M.; Pan, S.; Xu, X. Structure-activity relationship of flavonoids on their anti-Escherichia coli activity and inhibition of DNA gyrase. J. Agric. Food Chem. 2013, 61, 8185-8190. [CrossRef]

81. Tsuchiya, H. Membrane interactions of phytochemicals as their molecular mechanism applicable to the discovery of drug leads from plants. Molecules 2015, 20, 18923-18966. [CrossRef]

82. Sanver, D.; Murray, B.S.; Sadeghpour, A.; Rappolt, M.; Nelson, A.L. Experimental modeling of flavonoid-biomembrane interactions. Langmuir 2016, 32, 13234-13243. [CrossRef]

83. Eumkeb, G.; Chukrathok, S. Synergistic activity and mechanism of action of ceftazidime and apigenin combination against ceftazidime-resistant Enterobacter cloacae. Phytomedicine 2013, 20, 262-269. [CrossRef]

84. Soromou, L.W.; Zhang, Y.; Cui, Y.; Wei, M.; Chen, N.; Yang, X.; Huo, M.; Baldé, A.; Guan, S.; Deng, X.; et al. Subinhibitory concentrations of pinocembrin exert anti-Staphylococcus aureus activity by reducing $\alpha$-toxin expression. J. Appl. Microbiol. 2013, 115, 41-49. [CrossRef]

85. Ikigai, H.; Nakae, T.; Hara, Y.; Shimamura, T. Bactericidal catechins damage the lipid bilayer. BBA Biomembr. 1993, 1147, 132-136. [CrossRef]

86. Taylor, P.W.; Hamilton-Miller, J.M.; Stapleton, P.D. Antimicrobial properties of green tea catechins. Food Sci. Technol. Bull. 2005, 2, 71-81. [CrossRef]

87. Yam, T.S.; Hamilton-Miller, J.M.; Shah, S. The effect of a component of tea (Camellia sinensis) on methicillin resistance, PBP2'synthesis, and beta-lactamase production in Staphylococcus aureus. J. Antimicrob. Chemother. 1998, 42, 211-216. [CrossRef]

88. Mandalari, G.; Bennett, R.N.; Bisignano, G.; Trombetta, D.; Saija, A.; Faulds, C.B.; Gasson, M.J.; Narbad, A. Antimicrobial activity of flavonoids extracted from bergamot (Citrus bergamia Risso) peel, a byproduct of the essential oil industry. J. Appl. Microbiol. 2007, 103, 2056-2064. [CrossRef]

89. Puupponen-Pimiä, R.; Nohynek, L.; Ammann, S.; Oksman-Caldentey, K.-M.; Buchert, J. Enzyme-assisted processing increases antimicrobial and antioxidant activity of bilberry. J. Agric. Food Chem. 2008, 56, 681-688. [CrossRef]

90. Ratz-Łyko, A.; Arct, J. Evaluation of antioxidant and antimicrobial properties of enzymatically hydrolysed Cucurbita pepo and Linum usitatissimum seedcakes. Food Sci. Biotechnol. 2015, 24, 1789-1796. [CrossRef]

91. Skandamis, P.N.; Nychas, G.-J.E. Quorum sensing in the context of food microbiology. Appl. Environ. Microbiol. 2012, 78, 5473-5482. [CrossRef]

92. Li, Y.-H.; Tian, X. Quorum sensing and bacterial social interactions in biofilms. Sensors 2012, 12, $2519-2538$. [CrossRef]

93. Schaefer, A.L.; Greenberg, E.P.; Oliver, C.M.; Oda, Y.; Huang, J.J.; Bittan-Banin, G.; Peres, C.M.; Schmidt, S.; Juhaszova, K.; Sufrin, J.R.; et al. A new class of homoserine lactone quorum-sensing signals. Nature 2008, 454, 595-599. [CrossRef]

94. Ryan, R.P.; McCarthy, Y.; Watt, S.A.; Niehaus, K.; Dow, J.M. Intraspecies signaling involving the diffusible signal factor BDSF (cis-2-dodecenoic acid) influences virulence in Burkholderia cenocepacia. J. Bacteriol. 2009, 191, 5013-5019. [CrossRef]

95. Liu, Y.-C.; Hussain, F.; Negm, O.; Paiva, A.C.; Halliday, N.; Dubern, J.-F.; Singh, S.; Muntaka, S.; Wheldon, L.; Luckett, J.; et al. Contribution of the alkylquinolone quorum-sensing system to the interaction of Pseudomonas aeruginosa with bronchial epithelial cells. Front. Microbiol. 2018, 9, 3018. [CrossRef] [PubMed]

96. Krzyżek, P. Challenges and limitations of anti-quorum sensing therapies. Front. Microbiol. 2019, 10, 2473. [CrossRef] [PubMed] 
97. Lönn-Stensrud, J.; Landin, M.A.; Benneche, T.; Petersen, F.C.; Scheie, A.A. Furanones, potential agents for preventing Staphylococcus epidermidis biofilm infections? J. Antimicrob. Chemother. 2009, 63, 309-316. [CrossRef] [PubMed]

98. Husain, A.; Khan, S.A.; Iram, F.; Iqbal, M.A.; Asif, M. Insights into the chemistry and therapeutic potential of furanones: A versatile pharmacophore. Eur. J. Med. Chem. 2019, 171, 66-92. [CrossRef]

99. Galiè, S.; García-Gutiérrez, C.; Miguélez, E.M.; Villar, C.J.; Lombó, F. Biofilms in the food industry: Health aspects and control methods. Front. Microbiol. 2018, 9, 898. [CrossRef]

100. Hoffman, L.R.; D'Argenio, D.A.; MacCoss, M.J.; Zhang, Z.; Jones, R.A.; Miller, S.I. Aminoglycoside antibiotics induce bacterial biofilm formation. Nature 2005, 436, 1171-1175. [CrossRef]

101. Miquel, S.; Lagrafeuille, R.; Souweine, B.; Forestier, C. Anti-biofilm activity as a health issue. Front. Microbiol. 2016, 7, 592. [CrossRef]

102. Brackman, G.; Coenye, T. Quorum sensing inhibitors as anti-biofilm agents. Curr. Pharm. Des. 2015, $21,5-11$. [CrossRef]

103. Jiang, Q.; Chen, J.; Yang, C.; Yin, Y.; Yao, K. Quorum sensing: A prospective therapeutic target for bacterial diseases. BioMed Res. Int. 2019, 2019, 2015978. [CrossRef]

104. Machado, I.; Silva, L.R.; Giaouris, E.D.; Melo, L.F.; Simões, M. Quorum sensing in food spoilage and natural-based strategies for its inhibition. Food Res. Int. 2020, 127, 108754. [CrossRef]

105. Silva, L.N.; Zimmer, K.R.; Macedo, A.J.; Trentin, D.S. Plant natural products targeting bacterial virulence factors. Chem. Rev. 2016, 116, 9162-9236. [CrossRef] [PubMed]

106. Slobodníková, L.; Fialová, S.; Rendeková, K.; Kováč, J.; Mučaji, P. Antibiofilm activity of plant polyphenols. Molecules 2016, 21, 1717. [CrossRef] [PubMed]

107. Asfour, H.Z. Anti-quorum sensing natural compounds. J. Microsc. Ultrastruct. 2018, 6, 1-10. [CrossRef] [PubMed]

108. Borges, A.; Saavedra, M.J.; Simões, M. The activity of ferulic and gallic acids in biofilm prevention and control of pathogenic bacteria. Biofouling 2012, 28, 755-767. [CrossRef] [PubMed]

109. Eydelnant, I.A.; Tufenkji, N. Cranberry derived proanthocyanidins reduce bacterial adhesion to selected biomaterials. Langmuir 2008, 24, 10273-10281. [CrossRef]

110. Xu, X.; Zhou, X.D.; Wu, C.D. The tea catechin epigallocatechin gallate suppresses cariogenic virulence factors of Streptococcus mutans. Antimicrob. Agents Chemother. 2011, 55, 1229-1236. [CrossRef]

111. Khokhani, D.; Zhang, C.; Li, Y.; Wang, Q.; Zeng, Q.; Yamazaki, A.; Hutchins, W.; Zhou, S.-S.; Chen, X.; Yang, C.-H. Discovery of plant phenolic compounds that act as type III secretion system inhibitors or inducers of the fire blight pathogen, Erwinia amylovora. Appl. Environ. Microbiol. 2013, 79, 5424-5436. [CrossRef]

112. Vattem, D.A.; Mihalik, K.; Crixell, S.H.; McLean, R.J.C. Dietary phytochemicals as quorum sensing inhibitors. Fitoterapia 2007, 78, 302-310. [CrossRef]

113. Priha, O.; Virkajärvi, V.; Juvonen, R.; Puupponen-Pimiä, R.; Nohynek, L.; Alakurtti, S.; Pirttimaa, M.; Storgårds, E. Quorum sensing signalling and biofilm formation of brewery-derived bacteria, and inhibition of signalling by natural compounds. Curr. Microbiol. 2014, 69, 617-627. [CrossRef]

114. Vandeputte, O.M.; Kiendrebeogo, M.; Rajaonson, S.; Diallo, B.; Mol, A.; El Jaziri, M.; Baucher, M. Identification of catechin as one of the flavonoids from Combretum albiflorum bark extract that reduces the production of quorum-sensing-controlled virulence factors in Pseudomonas aeruginosa PAO1. Appl. Environ. Microbiol. 2010, 76, 243-253. [CrossRef]

115. Vandeputte, O.M.; Kiendrebeogo, M.; Rasamiravaka, T.; Stévigny, C.; Duez, P.; Rajaonson, S.; Diallo, B.; Mol, A.; Baucher, M.; El Jaziri, M. The flavanone naringenin reduces the production of quorum sensing-controlled virulence factors in Pseudomonas aeruginosa PAO1. Microbiology 2011, 157, 2120-2132. [CrossRef] [PubMed]

116. Ouyang, J.; Sun, F.; Feng, W.; Sun, Y.; Qiu, X.; Xiong, L.; Liu, Y.; Chen, Y. Quercetin is an effective inhibitor of quorum sensing, biofilm formation and virulence factors in Pseudomonas aeruginosa. J. Appl. Microbiol. 2016, 120, 966-974. [CrossRef] [PubMed]

117. Vasavi, H.S.; Arun, A.B.; Rekha, P.-D. Anti-quorum sensing activity of Psidium guajava L. flavonoids against Chromobacterium violaceum and Pseudomonas aeruginosa PAO1. Microbiol. Immunol. 2014, 58, $286-293$. [CrossRef] [PubMed]

118. Lee, J.-H.; Regmi, S.C.; Kim, J.-A.; Cho, M.H.; Yun, H.; Lee, C.-S.; Lee, J. Apple flavonoid phloretin inhibits Escherichia coli O157: $\mathrm{H} 7$ biofilm formation and ameliorates colon inflammation in rats. Infect. Immun. 2011, 79, 4819-4827. [CrossRef] [PubMed] 
119. Girennavar, B.; Cepeda, M.L.; Soni, K.A.; Vikram, A.; Jesudhasan, P.; Jayaprakasha, G.K.; Pillai, S.D.; Patil, B.S. Grapefruit juice and its furocoumarins inhibits autoinducer signaling and biofilm formation in bacteria. Int. J. Food Microbiol. 2008, 125, 204-208. [CrossRef]

120. Vikram, A.; Jayaprakasha, G.K.; Jesudhasan, P.R.; Pillai, S.D.; Patil, B.S. Suppression of bacterial cell-cell signalling, biofilm formation and type III secretion system by citrus flavonoids. J. Appl. Microbiol. 2010, 109, 515-527. [CrossRef]

121. Sheng, L.; Olsen, S.A.; Hu, J.; Yue, W.; Means, W.J.; Zhu, M.J. Inhibitory effects of grape seed extract on growth, quorum sensing, and virulence factors of CDC "top-six" non-O157 Shiga toxin producing E. coli. Int. J. Food Microbiol. 2016, 229, 24-32. [CrossRef]

122. Luís, Â.; Silva, F.; Sousa, S.; Duarte, A.P.; Domingues, F. Antistaphylococcal and biofilm inhibitory activities of gallic, caffeic, and chlorogenic acids. Biofouling 2014, 30, 69-79. [CrossRef]

123. Lee, J.-H.; Kim, Y.-G.; Ryu, S.Y.; Cho, M.H.; Lee, J. Ginkgolic acids and Ginkgo biloba extract inhibit Escherichia coli O157: H7 and Staphylococcus aureus biofilm formation. Int. J. Food Microbiol. 2014, 174, 47-55. [CrossRef]

124. Bakkiyaraj, D.; Nandhini, J.R.; Malathy, B.; Pandian, S.K. The anti-biofilm potential of pomegranate (Punica granatum L.) extract against human bacterial and fungal pathogens. Biofouling 2013, 29, 929-937. [CrossRef]

125. Slobodníková, L.; Fialová, S.; Hupková, H.; Grančai, D. Rosmarinic acid interaction with planktonic and biofilm Staphylococcus aureus. Nat. Prod. Commun. 2013, 8, 1747-1750. [CrossRef]

126. Lin, M.-H.; Chang, F.-R.; Hua, M.-Y.; Wu, Y.-C.; Liu, S.-T. Inhibitory effects of 1,2,3,4,6-penta-O-galloyl- $\beta$-D-glucopyranose on biofilm formation by Staphylococcus aureus. Antimicrob. Agents Chemother. 2011, 55, 1021-1027. [CrossRef]

127. Cho, H.S.; Lee, J.-H.; Cho, M.H.; Lee, J. Red wines and flavonoids diminish Staphylococcus aureus virulence with anti-biofilm and anti-hemolytic activities. Biofouling 2015, 31, 1-11. [CrossRef]

128. Xu, C.; Yagiz, Y.; Hsu, W.-Y.; Simonne, A.; Lu, J.; Marshall, M.R. Antioxidant, antibacterial, and antibiofilm properties of polyphenols from muscadine grape (Vitis rotundifolia Michx.) pomace against selected foodborne pathogens. J. Agric. Food Chem. 2014, 62, 6640-6649. [CrossRef]

129. Rahman, M.R.T.; Lou, Z.; Yu, F.; Wang, P.; Wang, H. Anti-quorum sensing and anti-biofilm activity of Amomum tsaoko (Amommum tsao-ko Crevost et Lemarie) on foodborne pathogens. Saudi J. Biol. Sci. 2017, 24, 324-330. [CrossRef] [PubMed]

130. De Marco, S.; Piccioni, M.; Pagiotti, R.; Pietrella, D. Antibiofilm and antioxidant activity of propolis and bud poplar resins versus Pseudomonas aeruginosa. Evid. Based Complement. Altern. Med. 2017, 2017, 5163575. [CrossRef] [PubMed]

131. Maia, D.S.V.; Haubert, L.; Kroning, I.S.; Dos Santos Soares, K.; Oliveira, T.L.; Da Silva, W.P. Biofilm formation by Staphylococcus aureus isolated from food poisoning outbreaks and effect of Butia odorata Barb. Rodr. extract on planktonic and biofilm cells. LWT Food Sci. Technol. 2020, 117, 108685. [CrossRef]

132. Sharma, K.; Mahato, N.; Lee, Y.R. Systematic study on active compounds as antibacterial and antibiofilm agent in aging onions. J. Food Drug Anal. 2018, 26, 518-528. [CrossRef]

133. Edziri, H.; Jaziri, R.; Chehab, H.; Verschaeve, L.; Flamini, G.; Boujnah, D.; Hammami, M.; Aouni, M.; Mastouri, M. A comparative study on chemical composition, antibiofilm and biological activities of leaves extracts of four Tunisian olive cultivars. Heliyon 2019, 5, e01604. [CrossRef]

134. Nassima, B.; Nassima, B.; Riadh, K. Antimicrobial and antibiofilm activities of phenolic compounds extracted from Populus nigra and Populus alba buds (Algeria). Braz. J. Pharm. Sci. 2019, 55, e18114. [CrossRef]

135. Blando, F.; Russo, R.; Negro, C.; De Bellis, L.; Frassinetti, S. Antimicrobial and antibiofilm activity against Staphylococcus aureus of Opuntia ficus-indica (L.) Mill. cladode polyphenolic extracts. Antioxidants 2019, 8, 117. [CrossRef] [PubMed]

136. Famuyide, I.M.; Aro, A.O.; Fasina, F.O.; Eloff, J.N.; McGaw, L.J. Antibacterial and antibiofilm activity of acetone leaf extracts of nine under-investigated south African Eugenia and Syzygium (Myrtaceae) species and their selectivity indices. BMC Complement. Altern. Med. 2019, 19, 141. [CrossRef] [PubMed]

137. Radojević, I.D.; Branković, S.R.; Vasić, S.M.; Ćirić, A.R.; Topuzović, M.D.; Čomić, L.R. Phytochemical profiles, antioxidant and antimicrobial with antibiofilm activities of wild growing Potentilla visianii extracts. Nat. Prod. Commun. 2018, 13, 851-854. [CrossRef]

138. Stefanović, O.; Ličina, B.; Vasić, S.; Radojević, I.; Čomić, L. Bioactive extracts of Gentiana asclepiadea: Antioxidant, antimicrobial, and antibiofilm activity. Bot. Serbica 2018, 42, 223-229. 
139. Muñoz-Cazares, N.; García-Contreras, R.; Pérez-López, M.; Castillo-Juárez, I. Phenolic compounds with anti-virulence properties. In Phenolic Compounds-Biological Activity; Marcos Soto-Hernandez, M., Palma-Tenango, M., Del Rosario Garcia-Mateos, M., Eds.; IntechOpen: London, UK, 2017; pp. 139-167.

140. Fisher, E.L.; Otto, M.; Cheung, G.Y. Basis of virulence in enterotoxin-mediated staphylococcal food poisoning. Front. Microbiol. 2018, 9, 436. [CrossRef]

141. Argudín, M.Á.; Mendoza, M.C.; Rodicio, M.R. Food poisoning and Staphylococcus aureus enterotoxins. Toxins 2010, 2, 1751-1773. [CrossRef]

142. Albano, M.; Alves, F.C.B.; Andrade, B.F.M.T.; Barbosa, L.N.; Pereira, A.F.M.; Da Cunha, M.; Rall, V.L.M.; Júnior, A.F. Antibacterial and anti-staphylococcal enterotoxin activities of phenolic compounds. Innov. Food Sci. Emerg. Technol. 2016, 38, 83-90. [CrossRef]

143. Rasooly, R.; Molnar, A.; Choi, H.-Y.; Do, P.; Racicot, K.; Apostolidis, E. In-vitro inhibition of staphylococcal pathogenesis by witch-hazel and green tea extracts. Antibiotics 2019, 8, 244. [CrossRef]

144. Qiu, J.; Feng, H.; Xiang, H.; Wang, D.; Xia, L.; Jiang, Y.; Song, K.; Lu, J.; Yu, L.; Deng, X. Influence of subinhibitory concentrations of licochalcone A on the secretion of enterotoxins A and B by Staphylococcus aureus. FEMS Microbiol. Lett. 2010, 307, 135-141. [CrossRef]

145. Souza, E.L.; Oliveira, C.E.V.; Stamford, T.L.M.; Conceição, M.L.; Gomes Neto, N.J. Influence of carvacrol and thymol on the physiological attributes, enterotoxin production and surface characteristics of Staphylococcus aureus strains isolated from foods. Braz. J. Microbiol. 2013, 44, 29-36. [CrossRef]

146. Shimamura, Y.; Aoki, N.; Sugiyama, Y.; Tanaka, T.; Murata, M.; Masuda, S. Plant-derived polyphenols interact with staphylococcal enterotoxin A and inhibit toxin activity. PLoS ONE 2016, 11, e0157082. [CrossRef]

147. Shimamura, Y.; Hirai, C.; Sugiyama, Y.; Shibata, M.; Ozaki, J.; Murata, M.; Ohashi, N.; Masuda, S. Inhibitory effects of food additives derived from polyphenols on staphylococcal enterotoxin A production and biofilm formation by Staphylococcus aureus. Biosci. Biotechnol. Biochem. 2017, 81, 2346-2352. [CrossRef] [PubMed]

148. Zhao, Y.; Zhu, A.; Tang, J.; Tang, C.; Chen, J. Comparative effects of food preservatives on the production of staphylococcal enterotoxin I from Staphylococcus aureus isolate. J. Food Qual. 2017, 2017, 9495314. [CrossRef]

149. Rasooly, R.; Do, P.M.; Friedman, M. Inhibition of biological activity of staphylococcal enterotoxin A (SEA) by apple juice and apple polyphenols. J. Agric. Food Chem. 2010, 58, 5421-5426. [CrossRef] [PubMed]

150. Braga, L.C.; Shupp, J.W.; Cummings, C.; Jett, M.; Takahashi, J.A.; Carmo, L.S.; Chartone-Souza, E.; Nascimento, A.M.A. Pomegranate extract inhibits Staphylococcus aureus growth and subsequent enterotoxin production. J. Ethnopharmacol. 2005, 96, 335-339. [CrossRef]

151. Tranter, H.S.; Tassou, S.C.; Nychas, G.J. The effect of the olive phenolic compound, oleuropein, on growth and enterotoxin B production by Staphylococcus aureus. J. Appl. Bacteriol. 1993, 74, 253-259. [CrossRef]

152. Reddy, S.; Taylor, M.; Zhao, M.; Cherubin, P.; Geden, S.; Ray, S.; Francis, D.; Teter, K. Grape extracts inhibit multiple events in the cell biology of cholera intoxication. PLoS ONE 2013, 8, e73390. [CrossRef]

153. Cherubin, P.; Garcia, M.C.; Curtis, D.; Britt, C.B.; Craft, J.W., Jr.; Burress, H.; Berndt, C.; Reddy, S.; Guyette, J.; Zheng, T.; et al. Inhibition of cholera toxin and other AB toxins by polyphenolic compounds. PLoS ONE 2016, 11, e0166477. [CrossRef]

154. Quiñones, B.; Massey, S.; Friedman, M.; Swimley, M.S.; Teter, K. Novel cell-based method to detect Shiga toxin 2 from Escherichia coli O157: H7 and inhibitors of toxin activity. Appl. Environ. Microbiol. 2009, 75, 1410-1416. [CrossRef] [PubMed]

(C) 2020 by the authors. Licensee MDPI, Basel, Switzerland. This article is an open access article distributed under the terms and conditions of the Creative Commons Attribution (CC BY) license (http://creativecommons.org/licenses/by/4.0/). 